Article

\title{
Synthesis, Bioevaluation and Structural Study of Substituted Phthalazin-1(2H)-ones Acting as Antifungal Agents
}

\author{
Marcos Derita ${ }^{1}$, Esther del Olmo ${ }^{2, *}$, Bianca Barboza ${ }^{2}$, Ana Esther García-Cadenas ${ }^{2}$, \\ José Luis López-Pérez ${ }^{2}$, Sebastián Andújar ${ }^{3,4}$, Daniel Enriz ${ }^{3,4}$, Susana Zacchino ${ }^{1, *}$ and \\ Arturo San Feliciano ${ }^{2}$
}

1 Pharmacognosy Department, Faculty of Biochemical and Pharmaceutical Sciences, National University of Rosario, Suipacha 531, 2000 Rosario, Argentine; E-Mail:mgderita@hotmail.com (M.D.)

2 Department of Pharmaceutical Chemistry, Faculty of Pharmacy, CIETUS-IBSAL, University of Salamanca, Campus Miguel de Unamuno, 37007 Salamanca, Spain; E-Mails: bianca.barboza@gmail.com (B.B.); anaester@usal.es (A.E.G.-C.); lopez@usal.es (J.L.L.-P.); asf@usal.es (A.S.F.)

3 Faculty of Chemistry, Biochemistry and Pharmacy, National University of San Luis (UNSL), Chacabuco 917, 5700 San Luis, Argentine; E-Mails: saanduja@unsl.edu.ar (S.A.); denriz@unsl.edu.ar (D.E.)

4 IMIBIO-CONICET, Universidad Nacional de San Luis, Chacabuco 915, 5700 San Luis, Argentina

* Authors to whom correspondence should be addressed; E-Mails: olmo@usal.es (E.D.O.); szaabgil@citynet.net.ar (S.Z.); Tel.: +34-923-294-528 (E.D.O.) Fax: +34-923-294-515 (E.D.O.).

Received: 14 January 2013; in revised form: 31 January 2013 / Accepted: 14 March 2013 / Published: 18 March 2013

\begin{abstract}
Twenty-five polysubstituted phthalazinone derivatives were synthesized and tested for their antifungal activity against a panel of pathogenic and clinically important yeasts and filamentous fungi. Among them, the compound 4-(4-chlorobenzyl)-2methylphthalazin-1(2H)-one (5) exhibited a remarkable antifungal activity against standardised strains of dermatophytes and Cryptococcus neoformans, as well as against some clinical isolates. A physicochemical study performed on compound $\mathbf{5}$ revealed its conformational and electronic characteristics, providing us with useful data for the future design of novel related antifungal analogues.
\end{abstract}


Keywords: benzylphthalazinones; antifungal; Cryptococcus neoformans; dermatophytes structure-activity relationships; conformational study

\section{Introduction}

Fungal infections have emerged as a major cause of morbidity and often of mortality in immunocompromised and debilitated patients over the past decades. A matter of concern in the treatment of fungal infections is the limited number of efficacious antifungal drugs available [1,2]. Many of the currently available drugs are toxic, produce recurrence or lead to the development of resistance, due in part to the prolonged periods of drug administration needed [3]. Although a new generation of triazoles, polyenes in lipidic formulations and echinocandins have been introduced, and several combination therapies have been configured as therapeutic alternatives during the last decade, fungal infections remain difficult to eradicate [3]. There is, therefore, a clear need of discovering new structures with antifungal properties, that could lead to the development of new useful agents for the management of fungal infections.

In the course of our on-going screening program for new and selective antifungal compounds, we have previously reported several series of antifungal compounds obtained from natural and synthetic sources [4-9]. Considering that some phthalazine derivatives, including some polybrominated compounds [10], 4-benzyl substituted ones [11] and others [12-15] have been evaluated for their antimicrobial and particularly antifungal activities against yeasts (Candida and Cryptococcus strains) and Aspergillus spp., we have prepared a series of twenty five differently substituted phthalazin-1-ones to evaluate their antifungal activities against a panel of representative clinically important fungal species. Then, taking into account the antifungal results, conformational and electronic studies on the most interesting compound of the series were carried out.

\section{Results and Discussion}

\subsection{Chemistry}

A first group of phthalazinones 1-13 (Scheme 1) was synthesized from the intermediate 4-benzalphthalides B1-B7 by treatment with either hydrazine or methyl hydrazine. Previously, the benzalphthalides were prepared in usually good though variable yields (90-45\%) by high temperature condensation of phthalic anhydride with mono-, di- or tri-substituted phenylacetic acids, in the presence of toluene and potassium carbonate following a reported procedure [16], with a slight variation. The condensation of benzalphthalides B1 to B4 and B6 with hydrazine hydrate at $80{ }^{\circ} \mathrm{C}$ during 6-8 $\mathrm{h}$ yielded the phthalazinones 1-4 and $\mathbf{1 2}$ respectively, while the reaction of benzalphthalides B1 to B5 and B7 with methylhydrazine under the same conditions gave phthalazinones 5-9 and 13, respectively.

According to our preliminary evaluation results of this first group of phthalazinones, which will be described below, the presence of the 4-chlorobenzyl substituent at position C-4 was considered as the most relevant feature for the antifungal activity. Consequently, such a moiety was maintained in the 
compounds synthesized later. Similarly, phthalazinones without a methyl group at the N-2 position failed to show any noticeable antifungal activity (MIC values $>250 \mu \mathrm{g} / \mathrm{mL}$ ), whereas the $N^{2}$-methylated analogues displayed from fair to good inhibition results. In the continuation of the research, the change of the methyl group at position N-2 of the phthalazinone for ethyl or allyl groups led to compounds $\mathbf{1 0}$ and 11, respectively. These compounds were synthesized through direct alkylation of the phthalazinone 1 with the corresponding alkyl or alkenyl bromide. Once evaluated, the $\mathrm{N}^{2}$-ethyl derivative was less active and less potent than the $N$-methyl analogue, and the $N$-allyl derivative resulted practically inactive. These observations influenced the criteria applied further in this research.

Scheme 1. Synthesis and structures of benzalphthalides B1-B7 and phthalazinones 1-13.
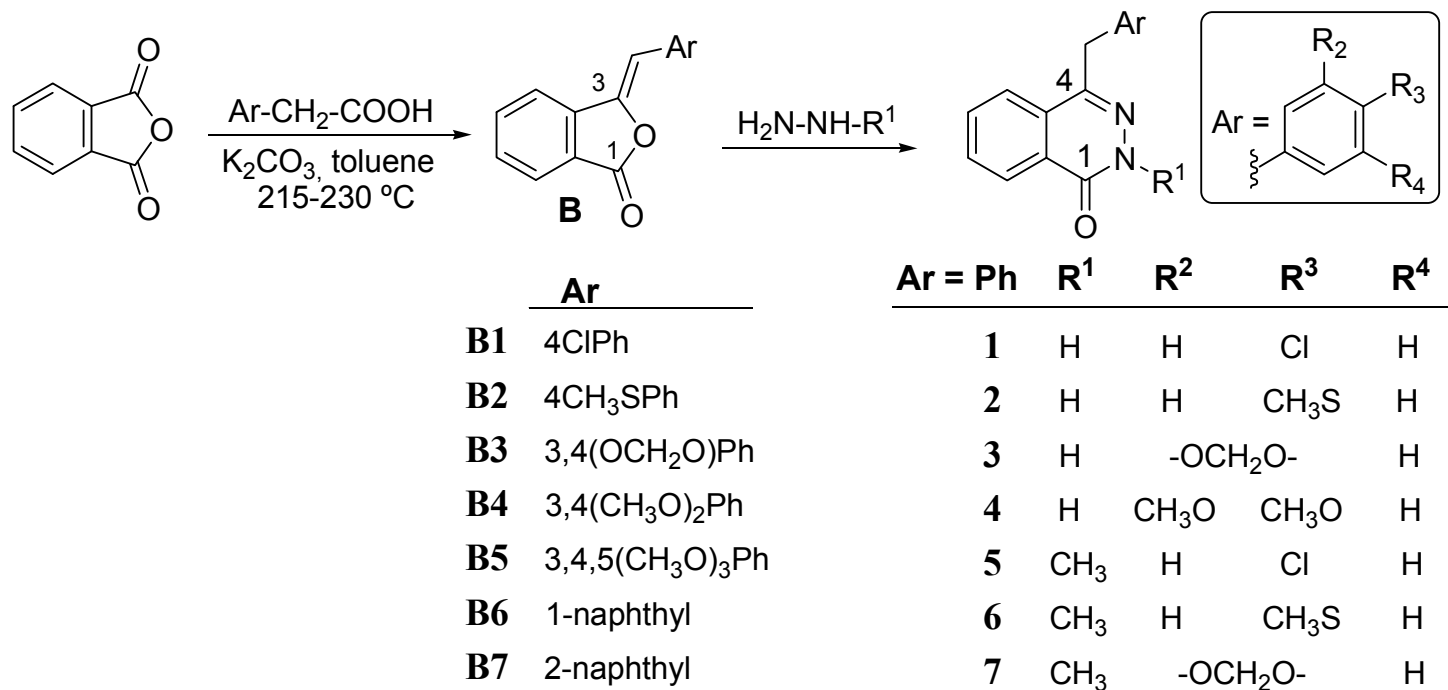

Ar $=$ Naphthyl

12 1-naphthyl $\left(\mathrm{R}^{1}=\mathrm{H}\right)$

13 2-naphthyl $\left(\mathrm{R}^{1}=\mathrm{CH}_{3}\right)$

\begin{tabular}{ccccc}
$\mathrm{Ar}=\mathbf{P h}$ & $\mathbf{R}^{1}$ & $\mathbf{R}^{2}$ & $\mathbf{R}^{3}$ & $\mathbf{R}^{4}$ \\
\hline 1 & $\mathrm{H}$ & $\mathrm{H}$ & $\mathrm{Cl}$ & $\mathrm{H}$
\end{tabular}

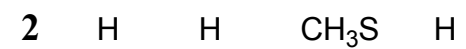

$3 \mathrm{H} \quad-\mathrm{OCH}_{2} \mathrm{O}-\mathrm{H}$

$\begin{array}{llllll}4 & \mathrm{H} & \mathrm{CH}_{3} \mathrm{O} & \mathrm{CH}_{3} \mathrm{O} & \mathrm{H}\end{array}$

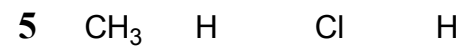

$\begin{array}{llllll}6 & \mathrm{CH}_{3} & \mathrm{H} & \mathrm{CH}_{3} \mathrm{~S} & \mathrm{H}\end{array}$

$7 \mathrm{CH}_{3} \quad-\mathrm{OCH}_{2} \mathrm{O}-\mathrm{H}$

$\begin{array}{lllll}8 & \mathrm{CH}_{3} & \mathrm{CH}_{3} \mathrm{O} & \mathrm{CH}_{3} \mathrm{O} & \mathrm{H}\end{array}$

$\begin{array}{llllll}9 & \mathrm{CH}_{3} & \mathrm{CH}_{3} \mathrm{O} & \mathrm{CH}_{3} \mathrm{O} & \mathrm{CH}_{3} \mathrm{O}\end{array}$

$\mathbf{1} \stackrel{\mathrm{R}^{1}-\mathrm{Br}}{\longrightarrow} \begin{array}{lllll}\mathbf{1 0} & \mathrm{C}_{2} \mathrm{H}_{5} & \mathrm{H} & \mathrm{Cl} & \mathrm{H} \\ \mathbf{1 1} & \text { Allyl } & \mathrm{H} & \mathrm{Cl} & \mathrm{H}\end{array}$

Thus, the next step was focused to the introduction of structural modifications on the aromatic ring of the starting phthalic anhydride, while retaining the 4-chlorobenzyl fragment at C-4 and the methyl group at N-2. The modifications of the phthalazine system included the introduction of substituents with electron donating $(\mathrm{Me})$, withdrawing $(\mathrm{Cl})$ and with extended resonance $\left(\mathrm{NO}_{2}\right)$ properties. The preparation of phthalazinones 14-25 was carried out by the procedures represented in Scheme 2. In several cases, a microwave (MW)-based procedure (method B) applied to improve reaction times and yields, also led to cleaner reaction products. The intermediate benzalphthalides B8-B16 were previously prepared by the procedure mentioned above. The benzalphthalides monosubstituted on the phthalazine system B8 to B11 and B13 were obtained as 1:1 mixtures of regioisomers with the substituent indistinctly attached at positions C-5 or C-6 of the benzalphthalide. The benzalphthalide B12 was obtained by sodium borohydride reduction of the mixed anhydride intermediate obtained by treatment of B11 with ethyl chloroformate in THF at low temperature $\left(-15^{\circ} \mathrm{C}\right)$, in the presence of triethylamine (TEA).

Phthalazinones 14-17 and 19-22 were obtained in good yields by treatment of the corresponding benzalphthalides with methyl hydrazine at $80^{\circ} \mathrm{C}$, during $6-8 \mathrm{~h}$. The phthalazinone 23 was obtained 
from phthalazinone $\mathbf{1 7}$ after treatment with diazomethane. The phthalazinone-aldehyde $\mathbf{2 4}$ was obtained from the 6(7)-hydroxymethylphthalazinone 18 under Swern oxidation conditions. Finally, the treatment of aldehyde $\mathbf{2 4}$ with hydroxylamine under reflux in ethanol yielded the phthalazinone $\mathbf{2 5}$ in good yield. Phthalazinones 20-22 were obtained by irradiation in a domestic multimode microwave (MW) apparatus. Equimolar amounts of benzalphthalides B14-B16 and methylhydrazine were mixed with $\mathrm{SiO}_{2}(10 \mathrm{~mol})$ and irradiated at $350 \mathrm{~W}$ during $1-6 \mathrm{~min}$, the mixture was percolated with ethyl acetate and the crude purified by column chromatography to provide the desired phthalazinones 20-22 in $60-70 \%$ yield. It is interesting to note the advantages of the MW-based procedure that led to cleaner reactions products in these cases and have previously served to prepare different phthalazine derivatives [17]. Indeed, when method A was applied to the dichlorinated benzalphthalides B14-B16 more complex reaction mixtures were obtained, in which, apart from the expected phthalazinones 20-22, in lowered yields, several compounds (not reported here) derived from chlorine substitution by methylhydrazinyl groups were also found.

Scheme 2. Synthesis and structures of benzalphthalides B8-B16 and phthalazinones 14-25.
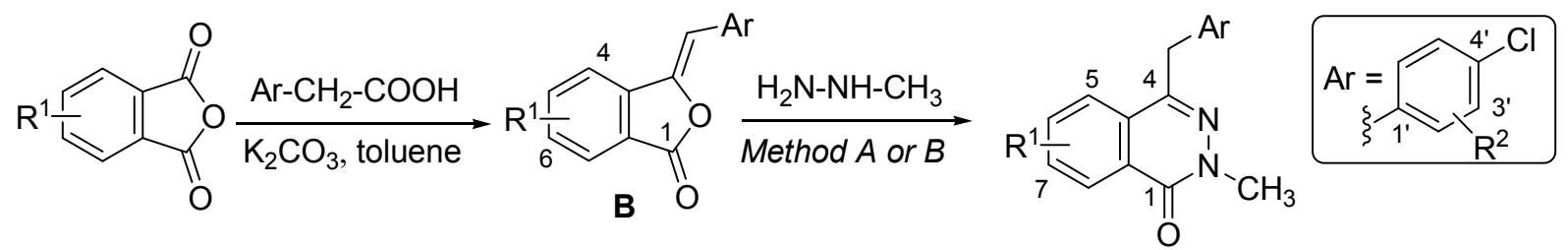

Method $A: \mathrm{K}_{2} \mathrm{CO}_{3}, \Delta /$ toluene Method B: $\mathrm{MW} / \mathrm{SiO}_{2}$

$17 \stackrel{\text { ii) }}{\longrightarrow} \mathrm{R}_{6(7)}^{1}=-\mathrm{COOCH}_{3}(\mathbf{2 3})$

B $\quad \mathbf{R}_{6(7)}^{1} \quad \mathbf{R}^{2}$ Comp. Method

$18 \stackrel{\text { iii) }}{\longrightarrow} \mathrm{R}_{6(7)}^{1}=-\mathrm{CHO}(\mathbf{2 4}) \stackrel{\text { iv) }}{\longrightarrow} \mathrm{R}_{6(7)}^{1}=-\mathrm{C}=\mathrm{NOH}(\mathbf{2 5})$

\begin{tabular}{|c|c|c|c|c|}
\hline B8 & $\mathrm{CH}_{3}$ & $\mathrm{H}$ & 14 & $A$ \\
\hline B9 & $\mathrm{CH}_{3}$ & $2-\mathrm{Cl}$ & 15 & $A$ \\
\hline B10 & $\mathrm{CH}_{3}$ & $3-\mathrm{Cl}$ & 16 & $A$ \\
\hline B11 & $\mathrm{COOH}$ & $\mathrm{H}$ & $17 i$ & $B$ \\
\hline B12 & $\mathrm{CH}_{2} \mathrm{OH}$ & $\mathrm{H}$ & $18^{\longleftarrow}$ & \\
\hline B13 & $\mathrm{NO}_{2}$ & $\mathrm{H}$ & 19 & $B$ \\
\hline B14 & $6,7 \mathrm{Cl}_{2}$ & $\mathrm{H}$ & 20 & $B$ \\
\hline B15 & $6,7 \mathrm{Cl}_{2}$ & $2-\mathrm{Cl}$ & 21 & $B$ \\
\hline 316 & $6,7 \mathrm{Cl}_{2}$ & $3-\mathrm{Cl}$ & 22 & $B$ \\
\hline
\end{tabular}

\subsection{Antifungal Activity}

The phthalazinone derivatives included in this research were tested in the range from 250 to $0.98 \mu \mathrm{g} / \mathrm{mL}$ against a panel of clinically important fungi including yeasts, hyalohyphomycetes and dermatophytes with the microbroth dilution method according to the CLSI guidelines $[18,19]$. Results against yeasts showed that none of the compounds inhibited the yeasts Candida albicans, Saccharomyces cerevisiae or the Aspergillus species filamentous fungi A. niger, A. fumigatus or A. flavus, with the exception of compound 5 that inhibited the standardized strain Cryptococcus neoformans ATCC 32264. In contrast, ten out of the twenty five phthalazinones tested (compounds 5-10, 14-16, 21) showed good to moderate activities against the dermatophytes Microsporum canis (M.c.), Microsporum gypseum (M.g.), Trichophyton mentagrophytes (T.m.)., Trichophyton rubrum (T.r.) and Epidermophyton floccosum (E.f.), being also compound 5 the most active substance (Tables 1 and 2). 
Table 1. Antifungal activity (MIC values, $\mu \mathrm{g} / \mathrm{mL}$ ) of phthalazinones 1-13 against dermatophytes.

\begin{tabular}{cccccc}
\hline Comp. & $\boldsymbol{E} . \boldsymbol{f}$. & M.c. & M.g. & T.r. & T.m. \\
\hline 1 & $i$ & $i$ & $i$ & $i$ & $i$ \\
2 & $i$ & $i$ & $i$ & $i$ & $i$ \\
3 & $i$ & $i$ & $i$ & $i$ & $i$ \\
4 & $i$ & $i$ & $i$ & $i$ & $i$ \\
5 & 6.25 & 6.25 & 25 & 12.5 & 25 \\
6 & 250 & 100 & 100 & 125 & 50 \\
7 & 100 & 125 & $i$ & 100 & $i$ \\
8 & 125 & 125 & $i$ & $i$ & 62.5 \\
9 & $i$ & $i$ & $i$ & 100 & 125 \\
10 & 50 & 62.5 & 50 & 50 & 50 \\
11 & $i$ & $i$ & $i$ & $i$ & $i$ \\
12 & $i$ & $i$ & $i$ & $i$ & $i$ \\
13 & $i$ & $i$ & $i$ & $i$ & $i$ \\
AmB & 0.075 & 0.50 & 0.125 & 0.075 & 0.075 \\
Terb & 0.04 & 0.04 & 0.04 & 0.01 & 0.025 \\
\hline
\end{tabular}

$i$ : Compound considered inactive (MIC $>250 \mu \mathrm{g} / \mathrm{mL}$ ); AmB: Amphotericin B; Terb: Terbinafine; E $f .=$ Epidermophyton floccosum; M.c. $=$ Microsporum canis; M.g. = M. gypseum; T.r. $=$ Trichophyton rubrum; T.m. $=$ T. mentagrophytes.

Table 2. Antifungal activity (MIC values, $\mu \mathrm{g} / \mathrm{mL}$ ) of phthalazinones $\mathbf{1 4 - 2 5}$ against dermatophytes.

\begin{tabular}{ccccc}
\hline Comp. & M.c. & M.g. & T.r. & T.m. \\
\hline 5 & 6.25 & 25 & 12.5 & 25 \\
14 & $i$ & 125 & 100 & 50 \\
15 & $i$ & 250 & 50 & 100 \\
16 & $i$ & $i$ & 100 & 100 \\
17 & $i$ & $i$ & $i$ & $i$ \\
18 & $i$ & $i$ & $i$ & $i$ \\
19 & $i$ & $i$ & $i$ & $i$ \\
20 & $i$ & $i$ & $i$ & $i$ \\
21 & $i$ & $i$ & $i$ & $i$ \\
22 & $i$ & $i$ & $i$ & $i$ \\
23 & $i$ & $i$ & $i$ & $i$ \\
24 & $i$ & $i$ & $i$ & $i$ \\
25 & $i$ & 125 & 100 & 100 \\
AmB & 0.50 & 0.125 & 0.075 & 0.075 \\
Terb & 0.04 & 0.04 & 0.01 & 0.025 \\
\hline
\end{tabular}

$i$ : Compounds considered inactive (MIC $>250 \mu \mathrm{g} / \mathrm{mL}$ ); AmB: Amphotericin B; Terb: Terbinafine; E.f. = Epidermophyton floccosum; M.c. = Microsporum canis; M.g. = M. gypseum; T.r. $=$ Trichophyton rubrum; T.m. $=$ T. mentagrophytes. ${ }^{\S}$ Compounds with only one substituent at position 6 (7), actually contain 1:1 mixtures of both regioisomers. 


\subsubsection{Analysis of the Activity against Dermatophytes}

Table 1 summarizes the results of the antifungal activity found for phthalazinones 1-13, all of which possess no substituent at the fused benzene ring of the phthalazine system. As it can be seen, the phthalazinone derivatives 1-4 and 12, without substitution at N-2, were inactive (MIC values > $250 \mu \mathrm{g} / \mathrm{mL}$ ). The comparison between those 2-methyl compounds $\mathbf{1}, \mathbf{5}, \mathbf{1 0}$ and 11, easily led us to define the Me group as the best substituent at N-2, within those compounds tested. However, it is noteworthy that the N-Me substitution is not by itself sufficient for phthalazinones to display antifungal activity, since a change of the substituent at C-4 (benzyl to 2-naphthylmethyl), led to compound 13 which is devoid of antifungal activity. At this respect, another fact that can be observed when comparing the results related to the absence or presence of a 4-chlorobenzyl substituent at C-4, that seems to be determinant for the activity and is present in the two most potent compounds of this group, 5 and 10. Accordingly, the concurrence of both substituents, $\mathrm{Me}$ on $\mathrm{N}-2$, and $\mathrm{Cl}$ at the $p$-position of benzyl group, would be the structural features that combine for the antifungal properties of compound 5 .

Other substituents (MeS-, $-\mathrm{OCH}_{2} \mathrm{O}-, \mathrm{MeO}-$ ) on the benzyl side chain along with $\mathrm{N}-\mathrm{Me}$, provide the antifungal phthalazinones 6-9, which showed just moderate activity. In addition, the comparison of antifungal potencies of compounds 1 vs. 5, 2 vs. 6, 3 vs. 7 and 4 vs. 8 showed that the different substituents at the $p$-position of the benzyl moiety need to be accompanied by an N-Me group to show antifungal activity.

The interesting antifungal activities of compound $\mathbf{5}$ led us to prepare the analogues 14-25, all of them containing both a Me substituent at N-2 and the 4-chlorobenzyl fragment at the C-4 position. These compounds were evaluated against the complete panel of fungi, though only positive results are included in Table 2.

Activity results in Table 2 show that the introduction of a methyl substituent at C-6(7) (compounds 14-16) rendered compounds with $2-10$ times lower antifungal activity than compound 5 and a narrower spectrum of action. Interestingly enough, the change of the $\mathrm{Me}$ on $\mathrm{C}-6(7)$ to a variety of electron-withdrawing groups as $\mathrm{COOH}, \mathrm{COOMe}, \mathrm{CH}_{2} \mathrm{OH}, \mathrm{NO}_{2}$ or $\mathrm{CHO}$ (compounds 17-19 and 23-24), or even the introduction of two chlorine substituents on C-6 and C-7 (compounds 20-22) led to inactive compounds. However, compound 25 with a hydroxylimino function at positions C-6(7), and the 4-chlorobenzyl group at C-4, showed moderate activity against three dermatophyte strains.

We note also that the addition of an extra chlorine substituent at either position 2' or 3' of the benzyl fragment attached to C-4 of the phthalazinone system in compounds 15, 16, 21 and 22 did not produce significant changes in the antifungal activity in comparison with their respective monosubstituted 4-ClBn analogues 14 and 20.

\subsubsection{Analysis of the Activity against Yeasts}

Results against yeasts showed that compound $\mathbf{5}$ was the only one that showed antifungal activity in at least one yeast (C. neoformans) of the panel with a value of $\mathrm{MIC}=12.5 \mu \mathrm{g} / \mathrm{mL}$. C. neoformans remains as an important life-threatening complication for immunocompromised hosts, particularly for patients who have undergone transplantation of solid organs. The seriousness of this pathogenic yeast has increased in the last decade, because of the appearance of fluconazole-resistant Cryptococcus 
strains. Consequently, new compounds acting against this fungus are highly desirable [20,21]. Therefore, we decided to test compound $\mathbf{5}$ against an extended panel of $C$. neoformans clinical isolates provided by the Malbrán Institute (MI, Buenos Aires, Argentina). The results are shown in Table 3. For the sake of comparison the MIC and Minimum Fungicidal Concentration (MFC), values found against an ATCC standardized strain of $C$. neoformans are included. MIC values were determined against this new panel by using three endpoints: $\mathrm{MIC}_{100}, \mathrm{MIC}_{80}$ and $\mathrm{MIC}_{50}$ (the minimum concentration of compounds that inhibit 100, 80 and $50 \%$ of fungal growth, respectively). The application of less stringent endpoints such as $\mathrm{MIC}_{80}$ and $\mathrm{MIC}_{50}$ has been shown to represent the in vitro activity of compounds more consistently [22] and many times provides a better correlation with other measurements of antifungal activity [23]. The evaluation of the MFC for compound 5 was accomplished by sub-culturing a sample of culture medium from MIC tubes showing no growth, onto drug-free agar plates.

Table 3. Minimum Inhibitory Concentration (MIC) and Minimum Fungicidal Concentration (MFC) values of phthalazinone $\mathbf{5}$ against clinical isolates of Cryptococcus neoformans.

\begin{tabular}{|c|c|c|c|c|c|c|c|c|}
\hline \multirow{2}{*}{ Strain } & \multirow{2}{*}{$\begin{array}{c}\text { Voucher } \\
\text { specimen }\end{array}$} & \multicolumn{4}{|c|}{ Phthalazinone 5} & \multirow{2}{*}{$\frac{\mathrm{AmB}}{\mathrm{MIC}_{100}}$} & \multirow{2}{*}{$\begin{array}{c}\text { Itz } \\
\text { MIC }_{100}\end{array}$} & \multirow{2}{*}{$\begin{array}{c}\text { Vcz } \\
\text { MIC }_{100}\end{array}$} \\
\hline & & $\mathrm{MIC}_{100}$ & $\mathrm{MIC}_{80}$ & $\mathrm{MIC}_{50}$ & MFC & & & \\
\hline C. neoformans & ATCC 32264 & 7.8 & 7.8 & 3.9 & 15.6 & 0.25 & 0.15 & $<0.015$ \\
\hline C. neoformans & IM 983040 & 3.9 & 3.9 & 3.9 & 7.8 & 0.13 & $<0.015$ & $<0.015$ \\
\hline C. neoformans & IM 972724 & 3.9 & 3.9 & 3.9 & 15.6 & 0.06 & 0.25 & $<0.015$ \\
\hline C. neoformans & IM 042074 & 15.6 & 7.8 & 3.9 & 31.3 & 0.25 & $<0.015$ & $<0.015$ \\
\hline C. neoformans & IM 983036 & $i$ & $i$ & $i$ & $i$ & 0.25 & $<0.015$ & $<0.015$ \\
\hline C. neoformans & IM 000319 & 125 & 62.5 & 31.3 & 250 & 0.13 & $<0.015$ & $<0.015$ \\
\hline C. neoformans & IM 972751 & 62.5 & 62.5 & 31.3 & 250 & 0.25 & $<0.015$ & $<0.015$ \\
\hline C. neoformans & IM 031631 & 62.5 & 31.3 & 15.6 & 125 & 0.25 & $<0.015$ & 0.03 \\
\hline C. neoformans & IM 031633 & 15.6 & 7.8 & 7.8 & 31.3 & 0.13 & 0.25 & 0.25 \\
\hline
\end{tabular}

$\mathrm{MIC}_{100}, \mathrm{MIC}_{80}$ and $\mathrm{MIC}_{50}$ : concentration of compound $5(\mu \mathrm{g} / \mathrm{mL})$ that inhibits 100,80 or $50 \%$ the control growth respectively. ATCC: Voucher specimen from American Type Culture Collection (Manassas, Virginia, USA); IM: specimens from the Malbrán Institute (Buenos Aires, Argentina). AmB = Amphotericin B; Itz = Itraconazole; $\mathrm{Vcz}=$ Voriconazole; $i$ MIC $\geq 250 \mu \mathrm{g} / \mathrm{mL}$.

Results in Table 3 showed that 5 was fungicidal rather than fungistatic against seven out of the eight clinical isolates. It displayed strong antifungal activity $\left(\mathrm{MIC}_{50}\right.$ and $\mathrm{MIC}_{80}$ between 3.9 and $15.6 \mu \mathrm{g} / \mathrm{mL}$ ) against five out of the eight clinical isolates tested, and showed lower but still significant activity against the rest of the isolates. Although MIC values of the reference drugs amphotericin B, itraconazole and voriconazole against Cryptococcus neoformans are considerably lower than those displayed by compound $\mathbf{5}$, it is worth to take into account that five or six $\mathrm{MIC}_{100}, \mathrm{MIC}_{80}$ or $\mathrm{MIC}_{50}$ values found for this compound against the nine fungal strains tested (Table 3), were lower than $20 \mu \mathrm{g} / \mathrm{mL}$, which is indicative of a high antifungal potency.

\subsection{Conformational and Electronic Study of Compound $\mathbf{5}$}

With the purpose of obtaining a better structural information, and aiming to facilitate future design of better drugs in this field, we conducted a computer-assisted conformational and electronic study on 
compound $\mathbf{5}$ focused on its spatial orientations and electronic distribution. Compound $\mathbf{5}$ looks like a simple conformational problem with mainly two torsional angles $\left(\theta_{1}\right.$ and $\theta_{2}$, Figure 1$)$. For the sake of clarity, we have given the names $\mathrm{A}, \mathrm{B}$ and $\mathrm{C}$ to the three rings of the whole molecule.

Figure 1. Phthalazinone 5 with definition of rings and main torsional angles.

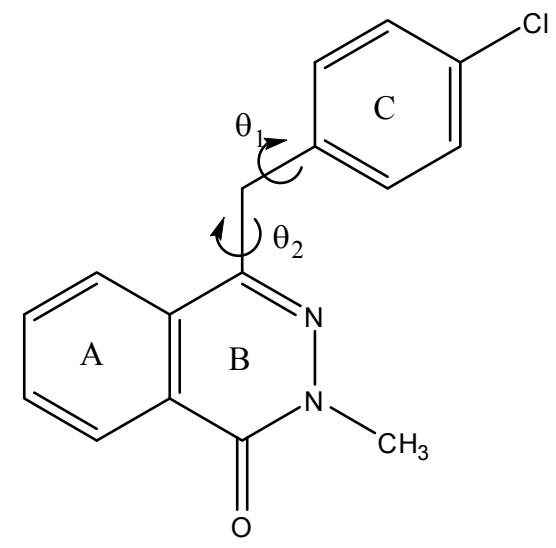

In a preliminary and exploratory step, the conformational study of this molecule was carried out from a double scan of $\theta 1$ vs. $\theta_{2}$ using semiempirical PM6 calculations. To obtain such a surface we rotated the torsional angle $\theta_{1}$ vs. $\theta_{2}$ each $20^{\circ}$. PM6 calculations predict that the conformationally allowed space for compound $\mathbf{5}$ is somewhat restricted. In this surface, we observed four conformational allowed zones; however, we noted that this compound possesses at least four equivalent conformers. The surface also suggests that the planar conformations possessing $\theta 2 \approx 180^{\circ}$ display very high energies. Although the semi-empirical calculations can define broad conformational features, one should employ a more accurate method, such as DFT calculations to ensure that the molecular flexibility and relative stability of the conformers are correct. Thus, we performed B3LYP/6-31G $(d, p)$ optimizations in order to confirm the preliminary results obtained from PM6 calculations. DFT optimizations confirm the semiempirical calculations giving four energetically equivalent conformations for this molecule. These preferred form displayed half-extended conformations. The conformational analysis of compound $\mathbf{5}$ requires, at this point, the evaluation of the flexibility, i.e., the energy determination of the transitional barrier between the predicted conformers. This is of crucial importance because, if the barriers are low, during a molecular recognition, this compound could be converted, with a low energy cost, to the preferred form. Energy profiles of compound 5 obtained from B3LYP/6-31G(d,p) calculations are given in Figure 2(A and B), which show the influence of ring orientations on the potential energy of the rotamers. To understand the significance of the rotation barrier, it is important to look not just to the magnitude of the energy barriers, but also to the complete behaviour energy $v$ s rotation angle. Figure 2(A) shows that B3LYP/6-31G(d,p) calculations predict two conformations for $\theta 1$, those with $\theta 1$ near to $130^{\circ}$ and $330^{\circ}$. We obtained barriers of about $2.5 \mathrm{Kcal} \mathrm{mol}^{-1}$ for the conformational interconversion at DFT level, indicating a significant molecular flexibility for this rotation. 
Figure 2. Potential Energy Curves (PECs) obtained for torsional the angles $\theta_{1}$ and $\theta_{2} \varphi_{1}$ of compound 5. The curves were calculated at B3LYP/6-31G(d,p) level of theory.

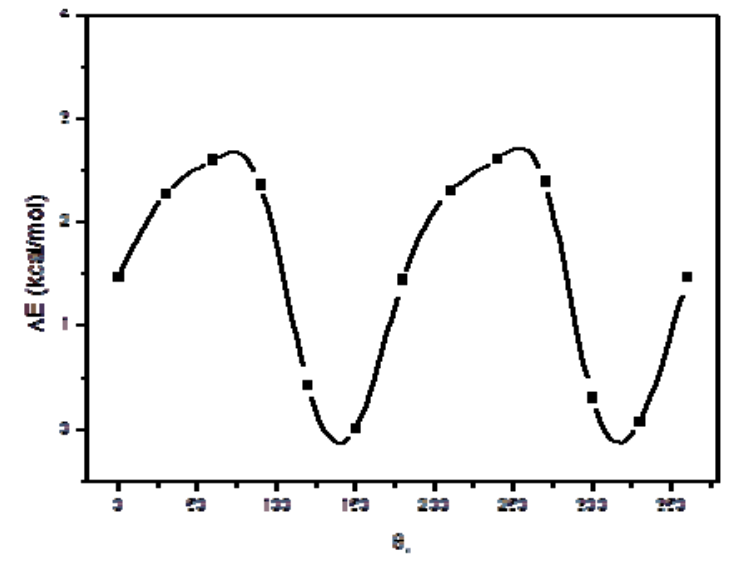

(A)

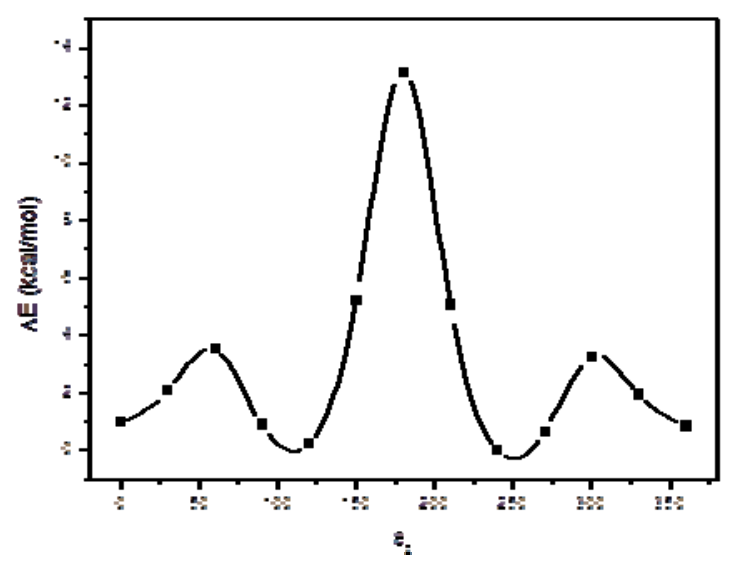

(B)

In turn, Figure 2B shows the rotational behaviour obtained for the torsional angle $\theta 2$. In this case, conformations near to $0.0^{\circ}, 120.0^{\circ}$ and $240^{\circ}$ are the preferred forms, whereas the planar form possessing $\theta 2$ near to $180^{\circ}$ is a markedly disfavoured conformation due to the steric hindrance. For this torsion, the barrier for the interconversions is somewhat higher $(3.8 \mathrm{Kcal} / \mathrm{mol})$ than that obtained for $\theta 1$. From these results, we can conclude that the molecular flexibility of this compound is significant but moderate.

Once obtained the energetically preferred form of compound 5, then we performed an electronic analysis using molecular electrostatic potentials (MEPs). Figure 3 shows the MEPs obtained for the preferred conformation of compound 5. The MEP map of this molecule exhibited three clear minima, one deep red zone located in the proximity of the carbonyl group $\left(\mathrm{V}_{(\mathrm{r})}\right.$ of about $\left.-0.045 \mathrm{el} / \mathrm{au}^{3}\right)$, a second minimum in the vicinity of the $\mathrm{N}$ atom (orange zone, $\mathrm{V}_{(\mathrm{r})}$ of about $-0.025 \mathrm{el} / \mathrm{au}^{3}$ ). Near to the ring $\mathrm{C}$ we observed a relatively extended hydrophobic zone (yellow and green area with $\mathrm{V}_{(\mathrm{r})}$ ranging from -0.02 to $\left.0.008 \mathrm{el} / \mathrm{au}^{3}\right)$. This third minimum correspond to ring $\mathrm{C}$ and from the $\mathrm{V}_{(\mathrm{r})}$ values obtained for this zone it is evident that the presence of a chlorine substituent at $p$-position of ring $\mathrm{C}$ polarizes this ring. We consider that, despite its symmetrical nature, this aromatic ring could make a specific contribution to the binding via its particular aromatic ring orientation. Thus, considering our experimental results, it appears that the presence of a chlorine substituent at the $p$-position at ring $\mathrm{C}$ could be important for attaining such an interaction. In this sense, the stereoelectronic changes induced by the presence of an additional chlorine atom, the common feature of many synthetic antifungal drugs, at the ortho or meta positions, could be the reason of the decreased activity found for the dichlorobenzyl derivatives 15, 16, 21 and 22 in comparison with $\mathbf{5}$.

Predictions of ADME, absorption and distribution parameters and the calculated physicochemical properties $(\log \mathrm{S}=-4.4, \operatorname{cog} \mathrm{P}=3.7$ ) for compound 5 and its analogues, are within the typical ranges desired for a drug, as well as the fulfillment of Lipinski's rule permit us to consider this substance as a good lead compound for antifungal activity. 
Figure 3. Electrostatic potential-encoded electron density surface obtained for compound $\mathbf{5}$.

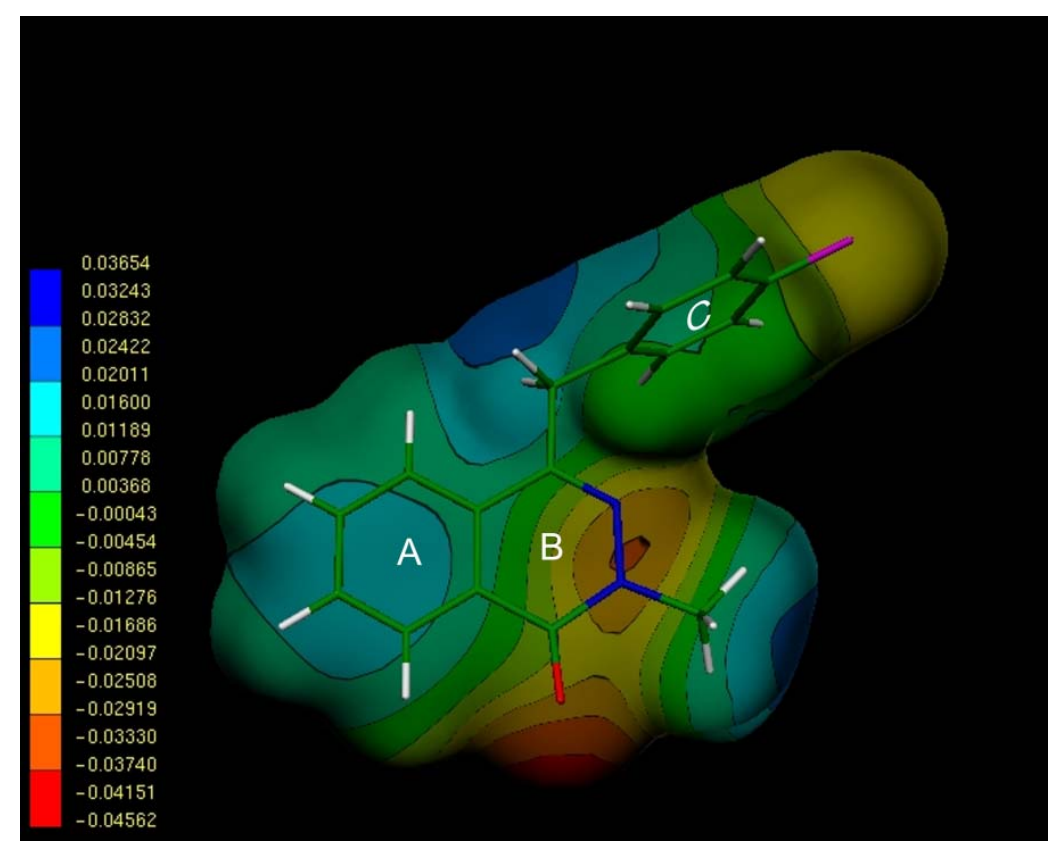

The surface was generated with GAUSSIAN 03 using a B3LYP/6-311++G(d,p) single point calculation. The colouring represents electrostatic potential with red indicating the strongest attraction to a positive point charge and blue indicating the strongest repulsion. The electrostatic potential is the energy of interaction of the positive point charge with the nuclei and electrons of a molecule. It provides a representative measure of overall molecular charge distribution. The colour-coding is shown on the left.

\section{Experimental}

\subsection{Chemistry}

Melting points ( $\mathrm{mp}$ ) were determined in a Büchi apparatus in open capillaries and were uncorrected. All commercial chemicals were used as purchased and solvents purified by the standard procedures prior to use [24]. Thin-layer chromatography was performed on Merck 60 silica gel GF-254 precoated plates and the identification was done with UV light and colorization with 10\% phosphomolybdic acid or ninhydrin spray followed by heating. Flash column chromatography was performed on Merck 60 silica gel (0.063-0.2 mesh). Infrared spectra were recorded using neat samples, without solvent or $\mathrm{KBr}$, on a FT-IR spectrometer Nicolet Impact 410 model. NMR spectra were recorded on Bruker AC $200(200 \mathrm{MHz})$ and Bruker DRX $400(400 \mathrm{MHz})$ instruments. Chemical shifts $(\delta)$ are expressed in parts per million (ppm) relative to the residual solvent peak: $\mathrm{CDCl}_{3} 7.26 \mathrm{ppm} / 77.0 \mathrm{ppm}$ and coupling constants $(J)$ are reported in Hertz $(\mathrm{Hz})$. High-resolution mass spectra (HRMS) were recorded on a QSTAR XL mass spectrometer, by electron spray ionisation (ESI-MS) technique $(5 \mathrm{kV})$.

\subsubsection{General Procedure for the Synthesis of Benzalphthalides B1-B16}

Phthalic anhydride $(2.2 \mathrm{mmol})$, the corresponding phenylacetic (naphthylacetic) acid $(2.7 \mathrm{mmol})$, sodium acetate $(0.26 \mathrm{mmol})$ and toluene $(5 \mathrm{~mL})$ were placed in a round-bottom flask to which a Dean-Stark separator was adapted. The mixtures were maintained at $210-245^{\circ} \mathrm{C}$ under nitrogen and 
with magnetic stirring for 9-33 h. After cooling, the reaction mixtures were dissolved with ethyl acetate and washed with aqueous $\mathrm{Na}_{2} \mathrm{CO}_{3}$ (sat.), brine and water, dried over $\mathrm{Na}_{2} \mathrm{SO}_{4}$ and concentrated under reduced pressure to give the crude reaction products. Solid products were purified by crystallization and oily products chromatographed over silica gel; yields ranged from $40-95 \%$. All the benzalphthalides were obtained as the $Z$ isomer, and the configuration was confirmed through NOE-difference and/or 2D-ROESY experiments.

(Z)-3-(4-Chlorobenzylidene)isobenzofuran-1-one (B1). Yield 75\%. Yellow crystals; mp 172-174 ${ }^{\circ} \mathrm{C}$; IR (KBr), $v_{\max }$ : 2919, 1796, 1656, 1450, 1366, 1270, 1078, 969, 850, 825, 758, $606 \mathrm{~cm}^{-1}$. ${ }^{1} \mathrm{H}-\mathrm{NMR} \delta$ : $6.30(\mathrm{~s}, 1 \mathrm{H}, \mathrm{H}-8), 7.30\left(\mathrm{~d}, J=8.8 \mathrm{~Hz}, 2 \mathrm{H}, \mathrm{H}-3^{\prime}+\mathrm{H}-5 '\right), 7.53(\mathrm{~d}, J=7.8 \mathrm{~Hz}, 1 \mathrm{H}, \mathrm{H}-4), 7.54(\mathrm{~m}, 1 \mathrm{H}$, H-6), 7.68 (m, 1H, H-5), 7.70 (d, $J=8.8 \mathrm{~Hz}, 2 \mathrm{H}, \mathrm{H}-2^{\prime}+\mathrm{H}-6$ '), 7.87 (d, $J=7.8 \mathrm{~Hz}, 1 \mathrm{H}, \mathrm{H}-7$ ) ppm. ${ }^{13} \mathrm{C}-\mathrm{NMR} \delta$ : 105.7 (C-8), 119.9 (C-4), 123.3 (C-7a), 125.6 (C-7), 129.0 (C-3' + C-5'), 130.0 (C-6), 131.3 (C-2' + C-6'), 131.6 (C-4'), 134.2 (C-1'), 134.7 (C-5), 140.3 (C-3a), 144.9 (C-3), 166.9 (C-1) ppm. ESI-MS: $m / z 257.0291[\mathrm{M}+\mathrm{H}]^{+}$; Anal. Calcd for $\mathrm{C}_{15} \mathrm{H}_{9} \mathrm{ClO}_{2}: \mathrm{C}, 70.19 ; \mathrm{H}, 3.53$. Found: C, 70.20; H, 3.49.

\subsubsection{General Procedure for the Synthesis of Phthalazinones 1-4 and 12}

Benzalphthalides B (1 mol) were mixed with an excess of hydrazine hydrate $(4 \mathrm{~mL})$, and few drops of toluene, and the mixture maintained at $70-80{ }^{\circ} \mathrm{C}$ under stirring for $3-12 \mathrm{~h}$. After cooling reaction mixtures were extracted with ethyl acetate and washed with water, dried over $\mathrm{Na}_{2} \mathrm{SO}_{4}$ and concentrated under reduced pressure to give crude products that were purified by flash chromatography on silica gel and/or crystallisation.

4-(4-Chlorobenzyl)phthalazin-1(2H)-one (1). Yield 77\%. Colourless oil. IR (NaCl), $v_{\max }: 3159,2902$, 1664, 1609, 1488, 1258, 815, 798, $684 \mathrm{~cm}^{-1} .{ }^{1} \mathrm{H}-\mathrm{NMR} \delta: 4.28$ (s, 2H, H-9), 7.21 (d, J=8.8 Hz, 2H, H-3' + H-5'), 7.27 (d, J=8.8 Hz, 2H, H-2' + H-6'), 7.75 (m, 3H, H-5 + H-6 + H-7), 8.47 (dd, J = 7.5, $2.5 \mathrm{~Hz}, 1 \mathrm{H}, \mathrm{H}-8$ ), 11.74 (br s, 1H, NH) ppm. ${ }^{13} \mathrm{C}-\mathrm{NMR} \delta: 38.2$ (C-9), $125.2(\mathrm{C}-7), 127.1$ (C-8), 128.3 (C-8a), $128.9\left(\mathrm{C}-4 \mathrm{a}+\mathrm{C}-3^{\prime}+\mathrm{C}^{\prime} 5^{\prime}\right), 129.9$ (C-2' + C-6'), 131.5 (C-5); 132.7 (C-1'), 133.6 (C-6), 136.0 (C-4'), 146.0 (C-4), 160.6 (C-1) ppm. ESI-MS: $m / z 271.0560[\mathrm{M}+\mathrm{H}]^{+}$; Anal. Calcd for $\mathrm{C}_{15} \mathrm{H}_{11} \mathrm{ClN}_{2} \mathrm{O}$ : C, 66.55; H, 4.10; N, 10.35. Found: C, 66.49; H, 4.11; N, 10.30 .

4-(4-Methylsulfanylbenzyl)phthalazin-1(2H)-one (2). Yield 50\%. Colourless oil. IR (NaCl), $v_{\max }: 3188$, 2920, 1657, 1492, 1260, 1017, 966, 793, $770 \mathrm{~cm}^{-1} .{ }^{1} \mathrm{H}-\mathrm{NMR} \delta: 2.43\left(s, 3 \mathrm{H}, \mathrm{SCH}_{3}\right), 4.26(s, 2 \mathrm{H}, \mathrm{H}-9)$, $7.18\left(\mathrm{~d}, J=8.0 \mathrm{~Hz}, 2 \mathrm{H}, \mathrm{H}-3^{\prime}+\mathrm{H}-5^{\prime}\right), 7.26$ (d, J=8.0 Hz, 2H, H-2' + H-6'), 7.73 (m, 3H, H-5 + H-6 + H-7), $8.46(\mathrm{~m}, 1 \mathrm{H}, \mathrm{H}-8), 11.48$ (br s, $1 \mathrm{H}, \mathrm{NH}) \mathrm{ppm} .{ }^{13} \mathrm{C}-\mathrm{NMR} \delta: 15.7\left(\mathrm{SCH}_{3}\right), 38.3(\mathrm{C}-9), 125.2(\mathrm{C}-7), 126.9$ (C-8 + C-3' + C-5'), 128.2 (C-8a), 128.9 (C-2' + C-6'), 129.7 (C-4a), 131.3 (C-5); 133.4 (C-6), 134.4 (C-1'), 136.7 (C-4'), 146.2 (C-4), 160.8 (C-1) ppm. ESI-MS: $m / z 283.0827[\mathrm{M}+\mathrm{H}]^{+}$; Anal. Calcd for $\mathrm{C}_{16} \mathrm{H}_{14} \mathrm{~N}_{2} \mathrm{OS}$ : C, 68.06; H, 5.00; N, 9.92. Found: C, 68.01; H, 4.96; N, 9.93.

4-(3,4-Methylenedioxybenzyl)phthalazin-1(2H)-one (3). Yield 100\%. Colourless oil. IR (NaCl), $v_{\max }$ : 3,216, 2916, 2852, 1661, 1496, 1248, 925, 860, $764 \mathrm{~cm}^{-1} .{ }^{1} \mathrm{H}-\mathrm{NMR} \delta: 4.20$ (s, 2H, H-9), 5.90 (br s, $2 \mathrm{H}, \mathrm{OCH}_{2} \mathrm{O}$ ), 6.73 (br s, 1H, H-2'), 6.74 (br s, 2H, H-5' + H-6'), 7.74 (m, 3H, H-5 + H-6 + H-7), 8.47 
(dd, $J=8.7,2.0 \mathrm{~Hz}, 1 \mathrm{H}, \mathrm{H}-8), 10.68$ (br s, $1 \mathrm{H}, \mathrm{NH}) \mathrm{ppm} .{ }^{13} \mathrm{C}-\mathrm{NMR} \delta: 38.5(\mathrm{C}-9), 101.1\left(\mathrm{OCH}_{2} \mathrm{O}\right)$, 108.5 (C-5'), 108.9 (C-2'), 121.5 (C-6'), 125.4 (C-7), 127.0 (C-8), 128.3 (C-8a), 129.8 (C-4a), 131.3 (C-1'), 131.5 (C-5); 133.6 (C-6), 146.5 (C-4 + C-3'), 148.0 (C-4'), 160.2 (C-1). ESI-MS: $m / z 281.0848$ $[\mathrm{M}+\mathrm{H}]^{+}$; Anal. Calcd for $\mathrm{C}_{16} \mathrm{H}_{12} \mathrm{~N}_{2} \mathrm{O}_{3}$ : C, 68.56; H, 4.32; N, 9.99. Found: C, 68.49; H, 4.26; N, 9.87.

4-(3,4-Dimethoxybenzyl)phthalazin-1(2H)-one (4). Yield 92\%. Colourless oil. IR (NaCl), $v_{\max }$ : 3294, 2919, 1651, 1514, 1352, 1259, 1029, 860, 783, $730 \mathrm{~cm}^{-1} .{ }^{1} \mathrm{H}-\mathrm{NMR} \delta: 3.82\left(\mathrm{~s}, 6 \mathrm{H}, 2 \times \mathrm{OCH}_{3}\right) ; 4.26(\mathrm{~s}$, 2H, H-9), 6.73 (br s, 1H, H-2'), 6.77 (d, $J=8.0 \mathrm{~Hz}, 1 \mathrm{H}, \mathrm{H}-5$ '), 7.74 (m, 3H, H-5 + H-6 + H-7), 7.82 (dd, $J=8.0,1.2 \mathrm{~Hz}, 1 \mathrm{H}, \mathrm{H}-6$ ), 8.47 (m, 1H, H-8), 11.50 (bs, 1H, NH) ppm. ${ }^{13} \mathrm{C}-\mathrm{NMR} \delta: 38.5$ (C-9), $55.8\left(2 \times \mathrm{OCH}_{3}\right), 111.2\left(\mathrm{C}-5^{\prime}\right), 115.5\left(\mathrm{C}-2^{\prime}\right), 120.4\left(\mathrm{C}-6^{\prime}\right), 125.4(\mathrm{C}-7), 126.9(\mathrm{C}-8), 128.2(\mathrm{C}-8 \mathrm{a})$, 129.8 (C-4a), 130.1 (C-1'), 131.2 (C-5), 133.3 (C-6), 146.5 (C-4), 147.9 (C-4'), 149.1 (C-3'), 161.0 (C-1) ppm. ESI-MS: $m / z 297.1161[\mathrm{M}+\mathrm{H}]^{+}$; Anal. Calcd for $\mathrm{C}_{17} \mathrm{H}_{16} \mathrm{~N}_{2} \mathrm{O}_{3}$ : C, 68.91; H, 5.44; N, 9.45. Found: C, 68.88; H, 5.39; N, 9.46.

1-Naphthylmethylphthalazin-1-one (12). Yield 98\%. Oil. IR ( $\mathrm{NaCl}), v_{\max }: 3417,2919,1653,1595$, 1470, 1023, 870, $787 \mathrm{~cm}^{-1} .{ }^{1} \mathrm{H}-\mathrm{NMR} \delta: 4.18(\mathrm{~s}, 2 \mathrm{H}, \mathrm{H}-9), 7.12$ (d, $J=7.0 \mathrm{~Hz}, 1 \mathrm{H}, \mathrm{H}-4$ '), 7.53 (m, 1H, H-5'), 7.55 (m, 1H, H-9'), 7.57 (m, 1H, H-8'), 7.74 (m, 3H, H-5 + H-6 + H-7), 7.75 (m, 1H, H-10'), 7.76 (m, 1H, H-6'), 8.18 (dd, $\left.J=8.2,1.8 \mathrm{~Hz}, 1 \mathrm{H}, \mathrm{H}-7^{\prime}\right), 8.44$ (dd, $J=8.4,2.0 \mathrm{~Hz}, 1 \mathrm{H}, \mathrm{H}-8$ ), 11.00 (br s, $1 \mathrm{H}, \mathrm{NH})$ ppm. ${ }^{13} \mathrm{C}-\mathrm{NMR} \delta: 35.3(\mathrm{C}-9), 123.1\left(\mathrm{C}-7^{\prime}\right), 125.1(\mathrm{C}-7), 125.5\left(\mathrm{C}-5^{\prime}\right), 126.1\left(\mathrm{C}-8^{\prime}\right), 126.4$ (C-9'), 127.2 (C-8 + C-4'), 127.7 (C-6'), 128.5 (C-8a), 128.9 (C-10'), 129.8 (C-4a), 131.3 (C-5), 131.9 (C-2'), 133.3 (C-1' + C-3'), 133.4 (C-6), 146.3 (C-4), 160.7 (C-1) ppm. ESI-MS: m/z 287.1106 $[\mathrm{M}+\mathrm{H}]^{+}$; Anal. Calcd for $\mathrm{C}_{19} \mathrm{H}_{14} \mathrm{~N}_{2} \mathrm{O}$ : C, 79.70; H, 4.93; N, 9.78. Found: C, 79.71; H, 4.89; N, 9.72.

\subsubsection{General Procedure for the Synthesis of Phthalazinones 5-9 and 14-16.}

Benzalphthalides B $(1 \mathrm{~mol})$ were mixed with an excess of methylhydrazine $(4 \mathrm{~mL})$, the mixtures maintained at $70-80{ }^{\circ} \mathrm{C}$ under stirring for 4-11 h. After cooling reaction mixtures were extracted with ethyl acetate and washed with water, dried over $\mathrm{Na}_{2} \mathrm{SO}_{4}$ and concentrated under reduced pressure to give crude products that were purified by flash chromatography on silica gel. In the case of compounds 14-16 the starting benzalphthalides were 1:1 mixtures or regioisomers with the substituent at positions C-5 and C-6 and correspondingly yielded mixtures of 6(7)-substituted phthalazinones in the same proportion.

4-(4-Chlorobenzyl)-2-methylphthalazin-1(2H)-one (5). Yield 75\%, oil. IR ( $\mathrm{NaCl}): v_{\max } 3068,2920$, 1650, 1587, 1489, 1262, 1093, 815, 797, 749, $700 \mathrm{~cm}^{-1} .{ }^{1} \mathrm{H}-\mathrm{NMR} \delta: 3.87$ (s, 3H, CH ), 4.25 (s, 2H, H-9), 7.20 (d, $J=8.8 \mathrm{~Hz}, 2 \mathrm{H}, \mathrm{H}-3^{\prime}+\mathrm{H}^{-5}$ '), 7.26 (d, $J=8.8 \mathrm{~Hz}, 2 \mathrm{H}, \mathrm{H}-2^{\prime}+\mathrm{H}-6$ '), 7.70 (m, 3H, H-5 + H-6 $+\mathrm{H}-7), 8.42(\mathrm{~m}, 1 \mathrm{H}, \mathrm{H}-8)$ ppm. ${ }^{13} \mathrm{C}-\mathrm{NMR} \delta: 38.3(\mathrm{C}-9), 39.4\left(\mathrm{CH}_{3}\right), 125.0(\mathrm{C}-7), 127.2(\mathrm{C}-8), 128.2$ (C-8a), 128.9 (C-3' + C-5'), 129.2 (C-4a), 129.8 (C-2' + C-6'), 131.3 (C-5); 132.8 (C-1' + C-6), 136.4 (C-4'), 144.5 (C-4), 159.6 (C-1) ppm. ESI-MS: $m / z$ 285.0716 [M+H] $]^{+}$; Anal. Calcd for $\mathrm{C}_{16} \mathrm{H}_{13} \mathrm{ClN}_{2} \mathrm{O}$ : C, 67.49; H, 4.60; N, 9.84. Found: C, 67.39; H, 4.52; N, 9.81.

2-Methyl-4-(4-methylsulfanylbenzyl)phthalazin-1(2H)-one (6). Yield 80\%, Colourless oil. IR (NaCl): $v_{\max } 2921,2852,1651,1585,1492,1435,1257,1080,810,795,775 \mathrm{~cm}^{-1} .{ }^{1} \mathrm{H}-\mathrm{NMR} \delta: 2.43(s, 3 \mathrm{H}$, 
$\left.\mathrm{SCH}_{3}\right), 3.86\left(\mathrm{~s}, 3 \mathrm{H}, \mathrm{NCH}_{3}\right), 4.23$ (s, 2H, H-9), 7.17 (d, $\left.J=8.8 \mathrm{~Hz}, 2 \mathrm{H}, \mathrm{H}-3^{\prime}+\mathrm{H}-5^{\prime}\right), 7.24$ (d, $J=8.8 \mathrm{~Hz}$, 2H, H-2' + H-6'), 7.67 (m, 3H, H-5 + H-6 + H-7), 8.43 (dd, $J=6.0,2.9 \mathrm{~Hz} 1 \mathrm{H}, \mathrm{H}-8)$ ppm. ${ }^{13} \mathrm{C}-\mathrm{NMR} \delta$ : $15.9\left(\mathrm{SCH}_{3}\right), 38.4(\mathrm{C}-9), 39.4\left(\mathrm{NCH}_{3}\right), 125.2(\mathrm{C}-7), 127.0\left(\mathrm{C}-8+\mathrm{C}-3^{\prime}+\mathrm{C}-5{ }^{\prime}\right), 128.2(\mathrm{C}-8 \mathrm{a}), 128.9\left(\mathrm{C}-2^{\prime}+\right.$ C-6'), 129.3 (C-4a), 131.2 (C-5); 132.8 (C-6), 134.8 (C-1'), 136.8 (C-4'), 143.9 (C-4), 159.6 (C-1) ppm. ESI-MS: $m / z 297.0983[\mathrm{M}+\mathrm{H}]^{+}$; Anal. Calcd for $\mathrm{C}_{17} \mathrm{H}_{16} \mathrm{~N}_{2} \mathrm{OS}: \mathrm{C}, 68.89 ; \mathrm{H}, 5.44 ; \mathrm{N}, 9.45$. Found: C, $68.81 ; \mathrm{H}, 5.43 ; \mathrm{N}, 9.39 ; \mathrm{S}, 10.76$.

2-Methyl-4-(3,4-methylenedioxybenzyl)phthalazin-1(2H)-one (7). Yield 65\%, Colourless oil. IR $(\mathrm{NaCl}): v_{\max } 2924,2854,1651,1586,1490,1245,1037,925,742,698 \mathrm{~cm}^{-1} .{ }^{1} \mathrm{H}-\mathrm{NMR} \delta: 3.89(s, 3 \mathrm{H}$, $\mathrm{CH}_{3}$ ), 4.19 (s, 2H, H-9), 5.90 (s, 2H, OCH${ }_{2} \mathrm{O}$ ), 6.70 (d, $\left.J=8.0 \mathrm{~Hz}, 1 \mathrm{H}, \mathrm{H}-5^{\prime}\right), 6.71$ (br s, 1H, H-2'), $6.74(\mathrm{~d}, J=8.0 \mathrm{~Hz}, 1 \mathrm{H}, \mathrm{H}-6 '), 7.69$ (m, 3H, H-5 + H-6 + H-7), 8.41 (m, 1H, H-8) ppm. ${ }^{13} \mathrm{C}-\mathrm{NMR} \delta$ : 38.6 (C-9), $39.4\left(\mathrm{CH}_{3}\right), 100.9\left(\mathrm{OCH}_{2} \mathrm{O}\right), 108.3\left(\mathrm{C}^{\prime} 5^{\prime}\right), 108.7\left(\mathrm{C}-2^{\prime}\right), 121.3\left(\mathrm{C}-6{ }^{\prime}\right), 125.1(\mathrm{C}-7), 127.0$ (C-8), 128.2 (C-8a), 129.2 (C-4a), 131.6 (C-1'), 131.1 (C-5); 132.6 (C-6), 145.1 (C-4), 146.3 (C-3'), 147.9 (C-4'), 159.6 (C-1) ppm. ESI-MS: $m / z 295.1004[\mathrm{M}+\mathrm{H}]^{+}$; Anal. Calcd for $\mathrm{C}_{17} \mathrm{H}_{14} \mathrm{~N}_{2} \mathrm{O}_{3}$ : C, 69.38; H, 4.79; N, 9.52. Found: C, 69.31; H, 4.77; N, 9.53.

4-(3,4-Dimethoxybenzyl)-2-methylphthalazin-1(2H)-one (8). Yield 93\%, Colourless oil. IR (NaCl): $v_{\max } 2926,1652,1515,1453,1260,1236,1029,791,744 \mathrm{~cm}^{-1} .{ }^{1} \mathrm{H}-\mathrm{NMR} \delta: 3.83\left(\mathrm{~s}, 6 \mathrm{H}, 2 \times \mathrm{OCH}_{3}\right)$, $3.89\left(s, 3 \mathrm{H}, \mathrm{CH}_{3}\right), 4.24$ (s, 2H, H-9), 6.77 (d, J=7.0 Hz, 1H, H-5'), 6.78 (s, 1H, H-2'), 6.79 (d, J = 7.0 Hz, 1H, H-6'), 7.69 (m, 3H, H-5 + H-6 + H-7), 8.44 (m, 1H, H-8) ppm. ${ }^{13} \mathrm{C}-\mathrm{NMR} \delta: 38.6$ (C-9), 39.4 $\left(\mathrm{CH}_{3}\right), 55.9\left(2 \times \mathrm{OCH}_{3}\right), 111.3\left(\mathrm{C}-5^{\prime}\right), 111.6\left(\mathrm{C}-2^{\prime}\right), 120.5\left(\mathrm{C}-6{ }^{\prime}\right), 125.2(\mathrm{C}-7), 127.0(\mathrm{C}-8), 128.2(\mathrm{C}-8 \mathrm{a})$, 128.4 (C-4a), 130.4 (C-1'), 131.2 (C-5), 132.7 (C-6), 145.2 (C-4), 147.9 (C-4'), 149.1 (C-3'), 159.6 (C-1) ppm. ESI-MS: $m / z$ 311, $1317[\mathrm{M}+\mathrm{H}]^{+}$; Anal. Calcd for $\mathrm{C}_{18} \mathrm{H}_{18} \mathrm{~N}_{2} \mathrm{O}_{3}$ : C, 69.66; H, 5.85; N, 9.03. Found: C, 69.59; H, 5.81; N, 9.04.

4-(3,4,5-Trimethoxybenzyl)-2-methylphthalazin-1(2H)-one (9). Yield 70\%, oil. IR (NaCl): $v_{\max }$ : 2937, 2837, 1651, 1587, 1330, 804, 776, $743 \mathrm{~cm}^{-1} .{ }^{1} \mathrm{H}-\mathrm{NMR} 3.77$ (s, 9H, $\left.3 \times \mathrm{OCH}_{3}\right), 3.89\left(\mathrm{~s}, 3 \mathrm{H}, \mathrm{CH}_{3}\right), 4.21$ (s, 2H, H-9), 6.44 (s, 2H, H-2' + H-6'), 7.68 (m, 3H, H-5 + H-6 + H-7), 8.42 (m, 1H, H-8) ppm. ${ }^{13} \mathrm{C}-\mathrm{NMR} \delta$ : $39.2(\mathrm{C}-9), 39.4\left(\mathrm{CH}_{3}\right), 56.1\left(2 \times \mathrm{OCH}_{3}\right), 60.8\left(\mathrm{OCH}_{3}\right), 105.4\left(\mathrm{C}-2^{\prime}+\mathrm{C}-6\right), 125.2(\mathrm{C}-7)$, 127.0 (C-8), 128.1 (C-8a), 129.4 (C-4a), 131.3 (C-5), 132.8 (C-6), 136.8 (C-1'), 145.0 (C-4), 153.4 $\left(\mathrm{C}-3^{\prime}+\mathrm{C}-4^{\prime}+\mathrm{C}-5^{\prime}\right), 159.6(\mathrm{C}-1)$ ppm. ESI-MS: $m / z 341.1423[\mathrm{M}+\mathrm{H}]^{+}$; Anal. Calcd for $\mathrm{C}_{19} \mathrm{H}_{20} \mathrm{~N}_{2} \mathrm{O}_{4}$ : C, 67.05; H, 5.92; N, 8.23. Found: C, 67.01; H, 5.88; N, 8.24.

2-Methyl-4-(naphthalen-2-ylmethyl)phthalazin-1(2H)-one (13). Yield 99\%, oil. IR ( $\mathrm{NaCl}): v_{\max } 3052$, 2926, 1651, 1584, 1257, 1033, 806, 785, 740, $691 \mathrm{~cm}^{-1} .{ }^{1} \mathrm{H}-\mathrm{NMR} \delta: 3.91\left(\mathrm{CH}_{3}\right) 4.39$ (s, 2H, H-9), 7.38 (m, 1H, H-5), 7.40 (m, 1H, H-7), 7.52 (m, 1H, H-6), 7.60 (m, 3H, H-7' + H-8' + H-9'), 7.65 (m, 1H, H-6'), 7.75 (m, 1H, H-10'), 7.77 (br s, 1H, H-2'), 7.78 (m, 1H, H-5'), 8.46 (m, 1H, H-8) ppm. ${ }^{13} \mathrm{C}-\mathrm{NMR}$

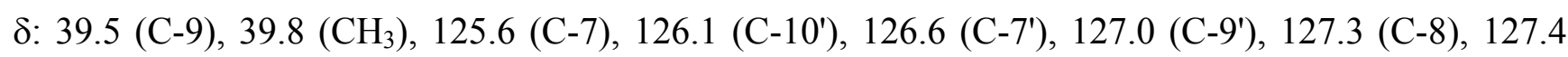
(C-6'), 128.0 (C-8'), 128.1 (C-8a), 128.5 (C-5'), 128.8 (C-2'), 129.7 (C-4a + C-5), 132.7 (C-1' + C-6), 133.9 (C-3'), 135.9 (C-4'), 145.3 (C-4), 160.0 (C-1) ppm. ESI-MS: $m / z 301.1263$ [M+H] ${ }^{+}$; Anal. Calcd for $\mathrm{C}_{20} \mathrm{H}_{16} \mathrm{~N}_{2} \mathrm{O}$ : C, 79.98; H, 5.37; N, 9.33. Found: C, 79.91; H, 5.39; N, 9.30. 
4-(4-Chlorobenzyl)-2,6(7)-dimethylphthalazin-1(2H)-one (14). Yield 93\%, oil. IR (NaCl): $v_{\max } 2922$, 1651, 1618, 1490, 1091, 1015, $838 \mathrm{~cm}^{-1}$. ESI-MS: $\mathrm{m} / z$ 299.0873 [M+H] $]^{+}$; Anal. Calcd for $\mathrm{C}_{17} \mathrm{H}_{15} \mathrm{ClN}_{2} \mathrm{O}$ : C, 68.34; H, 5.06; N, 9.38. Found: C, 68.19; H, 4.95; N, 9.40.

4-(4-Chlorobenzyl)-2,6-dimethylphthalazin-1(2H)-one (14a). ${ }^{1} \mathrm{H}-\mathrm{NMR} \delta: 2.42$ (s, 3H, $\left.\mathrm{CH}_{3}\right), 3.84$ (s, $3 \mathrm{H}, \mathrm{NCH}_{3}$ ), 4.21 (s, 2H, H-9), 7.24-7.22 (m, 4H, H-2' + H-6' and H-3' + H-5'), 7.40 (br s, 1H, H-5), $7.52(\mathrm{~d}, J=8.4,1 \mathrm{H}, \mathrm{H}-7), 8.30(\mathrm{~d}, J=8.4,1 \mathrm{H}, \mathrm{H}-8)$ ppm. ${ }^{13} \mathrm{C}-\mathrm{NMR} \delta: 21.8\left(\mathrm{CH}_{3}\right), 37.7(\mathrm{C}-9), 39.1$ $\left(\mathrm{NCH}_{3}\right), 124.3$ (C-5), $126.7(\mathrm{C}-8), 128.5$ (C-3'+ C-5'), $128.6(\mathrm{C}-8 \mathrm{a}), 128.9$ (C-4a), 129.5 (C-2' + C-6'), 132.2 (C-4'), 132.4 (C-7), 136.2 (C-1'), 144.1 (C-6), 143.3 (C-4), 159.2 (C-1) ppm.

4-(4-Chlorobenzyl)-2,7-dimethylphthalazin-1(2H)-one (14b). ${ }^{1} \mathrm{H}-\mathrm{NMR} \delta: 2.45$ (s, 3H, $\left.\mathrm{CH}_{3}\right), 3.85$ (s, $3 \mathrm{H}, \mathrm{NCH}_{3}$ ), 4.20 (s, 2H, H-9), 7.24-7.22 (m, 4H, H-2' + H-6' and H-3' + H-5'), 7.45 (d, J= 8.4 Hz, 2H, $\mathrm{H}-5+\mathrm{H}-6), 8.30$ (br s, 1H, H-8) ppm. ${ }^{13} \mathrm{C}-\mathrm{NMR} \delta: 21.4\left(\mathrm{CH}_{3}\right), 37.7$ (C-9), $39.1\left(\mathrm{NCH}_{3}\right), 124.7$ (C-5), 126.4 (C-8), 126.6 (C-8a), 127.7 (C-4a), 128.5 (C-3'+ C-5'), 129.5 (C-2' + C-6'), 132.2 (C-4'), 136.2 (C-1'), 138.3 (C-6), 141.8 (C-7), 143.3 (C-4), 159.2 (C-1).

4-(2,4-Dichlorobenzyl)-2,6(7)-dimethylphthalazin-1(2H)-one (15). Yield 94\%, oil. IR (NaCl): $v_{\max }$ 2921, 1653, 1618, 1472, 1347, 1048, 860, $837 \mathrm{~cm}^{-1}$. ESI-MS: $m / z$ 333, $0483[\mathrm{M}+\mathrm{H}]^{+}$; Anal. Calcd for $\mathrm{C}_{17} \mathrm{H}_{14} \mathrm{Cl}_{2} \mathrm{~N}_{2} \mathrm{O}$ : C, 61.28; H, 4.23; N, 8.41. Found: C, 61.30; H, 4.11; N, 8.30.

4-(2,4-Dichlorobenzyl)-2,6-dimethylphthalazin-1(2H)-one (15a). ${ }^{1} \mathrm{H}-\mathrm{NMR} \delta: 2.46$ (s, 3H, $\left.\mathrm{CH}_{3}\right), 3.81$ (s, 3H, $\mathrm{NCH}_{3}$ ), 4.29 (s, 2H, H-9), 7.00 (d, $J=8.4 \mathrm{~Hz}, \mathrm{H}-6$ '), 7.05 (dd, $J=8.4,1.8 \mathrm{~Hz}, \mathrm{H}-5$ '), 7.38 (d, $\left.J=1.8 \mathrm{~Hz}, \mathrm{H}-3^{\prime}\right), 7.48$ (s, 1H, H-5), 7.51 (d, $\left.J=8.0 \mathrm{~Hz}, 1 \mathrm{H}, \mathrm{H}-7\right), 8.32$ (d, $\left.J=8.0 \mathrm{~Hz}, 1 \mathrm{H}, \mathrm{H}-8\right)$ ppm. ${ }^{13} \mathrm{C}-\mathrm{NMR}$ 8: $21.9\left(\mathrm{CH}_{3}\right), 34.9(\mathrm{C}-9), 39.1\left(\mathrm{NCH}_{3}\right), 124.0(\mathrm{C}-5), 126.7(\mathrm{C}-8), 127.0\left(\mathrm{C}-5{ }^{\prime}\right), 127.8$ (C-8a), 129.1 (C-4a + C-6'), 130.7 (C-3'), 132.7 (C-7), 132.9 (C-2'), 134.1 (C-1' + C-4'), 143.1 (C-4), 143.6 (C-6), 159.3 (C-1) ppm.

4-(2,4-Dichlorobenzyl)-2,7-dimethylphthalazin-1(2H)-one (15b). ${ }^{1} \mathrm{H}-\mathrm{NMR} \delta: 2.49$ (s, 3H, $\left.\mathrm{CH}_{3}\right), 3.82$ (s, 3H, $\mathrm{NCH}_{3}$ ), 4.29 (s, 2H, H-9), 6.97 (d, $J=8.4 \mathrm{~Hz}, \mathrm{H}-6$ '), 7.10 (dd, $J=8.4,1.8 \mathrm{~Hz}, \mathrm{H}-5$ '), 7.38 (d, $J=1.8 \mathrm{~Hz}, \mathrm{H}-3$ ') 7.38 (d, 1H, $J=7.7 \mathrm{~Hz}, \mathrm{H}-6), 7.50$ (d, 1H, $J=7.7 \mathrm{~Hz}, \mathrm{H}-5), 8.32$ (br s, 1H, H-8) ppm. $\left.{ }^{13} \mathrm{C}-\mathrm{NMR} \delta: 21.6\left(\mathrm{CH}_{3}\right), 34.9(\mathrm{C}-9), 39.1\left(\mathrm{NCH}_{3}\right), 124.4(\mathrm{C}-5), 126.6(\mathrm{C}-8), 127.0(\mathrm{C}-5)^{\prime}\right), 125.6$ (C-8a), 129.1 (C-4a + C-6'), 130.7 (C-3'), 142.1 (C-7), 132.9 (C-2'), 134.1 (C-1' + C-4'), 143.4 (C-4), 134.1 (C-6), 159.3 (C-1) ppm.

4-(3,4-Dichlorobenzyl)-2,6(7)-dimethylphthalazin-1(2H)-one (16). Yield 86\%, oil. IR (NaCl): $\nu_{\max } 2921,1651,1618,1470,1347,1031,823 \mathrm{~cm}^{-1}$. ESI-MS: $m / z 333.0483[\mathrm{M}+\mathrm{H}]^{+}$; Anal. Calcd for $\mathrm{C}_{17} \mathrm{H}_{14} \mathrm{Cl}_{2} \mathrm{~N}_{2} \mathrm{O}_{2}$ : C, 61.28; H, 4.23; N, 8.41. Found: C, 61.17; H, 4.12; N, 8.49.

4-(3,4-Dichlorobenzyl)-2,6-dimethylphthalazin-1(2H)-one (16a). ${ }^{1} \mathrm{H}-\mathrm{NMR} \delta: 2.45$ (s, 3H, $\left.\mathrm{CH}_{3}\right), 3.84$ (s, 3H, $\mathrm{NCH}_{3}$ ), 4.20 (s, 2H, H-9), 7.10 (dd, $J=8.6,2.0 \mathrm{~Hz}, \mathrm{H}-6$ '), 7.33 (d, $J=8.6 \mathrm{~Hz}, \mathrm{H}-5$ '), 7.35 (d, $\left.J=2.0 \mathrm{~Hz}, \mathrm{H}-2^{\prime}\right), 7.39$ (s, 1H, H-5), 7.51 (d, $\left.J=8.0 \mathrm{~Hz}, 1 \mathrm{H}, \mathrm{H}-7\right), 8.32$ (d, $\left.J=9.0 \mathrm{~Hz}, 1 \mathrm{H}, \mathrm{H}-8\right)$ ppm. ${ }^{13} \mathrm{C}-\mathrm{NMR} \quad$ 8: $22.0\left(\mathrm{CH}_{3}\right), 37.6(\mathrm{C}-9), 39.2\left(\mathrm{NCH}_{3}\right), 124.3(\mathrm{C}-5), 125.8(\mathrm{C}-8 \mathrm{a}), 127.1(\mathrm{C}-8), 128.0$ $\left(\mathrm{C}-4 \mathrm{a}+5^{\prime}\right), 130.2\left(\mathrm{C}-2^{\prime}\right), 130.4\left(\mathrm{C}-6^{\prime}\right), 130.7$ (C-3'), 132.5 (C-4'), 132.8 (C-7), 138.1 (C-1'), 143.5 (C-4), 143.6 (C-6), 159.4 (C-1) ppm. 
4-(3,4-Dichlorobenzyl)-2,7-dimethylphthalazin-1(2H)-one (16b). ${ }^{1} \mathrm{H}-\mathrm{NMR} \delta: 2.48$ (s, 3H, $\left.\mathrm{CH}_{3}\right), 3.86$ (s, 3H, $\mathrm{NCH}_{3}$ ), 4.20 (s, 2H, H-9), 7.11 (dd, $J=8.0,2.0 \mathrm{~Hz}, \mathrm{H}-6$ '), 7.32 (d, $J=8.0,1.8 \mathrm{~Hz}, \mathrm{H}-5$ '), 7.35 (d, $\left.J=2.0 \mathrm{~Hz}, \mathrm{H}-2^{\prime}\right), 7.48$ (dd, $\left.1 \mathrm{H}, J=7.7,1.5 \mathrm{~Hz}, \mathrm{H}-6\right), 7.50$ (d, 1H, $\left.J=7.7 \mathrm{~Hz}, \mathrm{H}-5\right), 8.23$ (br s, 1H, $\mathrm{H}-8)$ ppm. ${ }^{13} \mathrm{C}-\mathrm{NMR} \delta: 21.6\left(\mathrm{CH}_{3}\right), 37.8(\mathrm{C}-9), 39.2\left(\mathrm{NCH}_{3}\right), 124.6(\mathrm{C}-5), 125.8(\mathrm{C}-8 \mathrm{a}), 126.8(\mathrm{C}-8)$, 128.0 (C-5'), 129.1 (C-4a), 130.4 (C-6'), 130.7 (C-3'), 130.2 (C-2'), 132.5 (C-4'), 134.1 (C-6), 138.1 (C-1'), 142.2 (C-7), 143.8 (C-4), 159.4 (C-1) ppm.

\subsubsection{Procedure for the Synthesis of Compounds $\mathbf{1 0}$ and $\mathbf{1 1}$}

A mixture of phthalazinone $1(0.20 \mathrm{mmol})$, ethyl bromide or allyl bromide $(0.22 \mathrm{mmol})$, potassium carbonate $(33 \mathrm{mg})$ and acetonitrile $(5 \mathrm{~mL})$ were maintained under reflux for $25 \mathrm{~h}$. Solvent was removed under vacuum and the crude mixture dissolved in ethyl acetate, washed with water, dried over $\mathrm{Na}_{2} \mathrm{SO}_{4}$ and concentrated under reduced pressure to give crude products that were purified by flash chromatography on silica gel.

4-(4-Chlorobenzyl)-2-ethylphthalazin-1(2H)-one (10). Yield 89\%, Colourless oil. IR (NaCl): $v_{\max } 2930,1650,1585,1350,1262,1090,830,798,691 \mathrm{~cm}^{-1} .{ }^{1} \mathrm{H}-\mathrm{NMR} \delta: 1.43(\mathrm{t}, J=7.3 \mathrm{~Hz}, 3 \mathrm{H}$, $\left.\mathrm{CH}_{3}\right), 4.26$ ( $\left.s, 2 \mathrm{H}, \mathrm{H}-9\right), 4.33$ (q, $\left.J=7.3 \mathrm{~Hz}, 2 \mathrm{H}, \mathrm{CH}_{2}\right), 7.18$ (d. $\left.J=8.5 \mathrm{~Hz}, \mathrm{H}-3^{\prime}+\mathrm{H}-5^{\prime}\right), 7.26(\mathrm{~d}, J=$ $\left.8.5 \mathrm{~Hz}, 2 \mathrm{H}, \mathrm{H}-2^{\prime}+\mathrm{H}^{\prime} 6^{\prime}\right), 7.66$ (m, 3H, H-5 + H-6 + H-7), 8.45 (m, 1H, H-8) ppm. ${ }^{13} \mathrm{C}-\mathrm{NMR} \delta: 13.6$ $\left(\mathrm{CH}_{3}\right), 38.3(\mathrm{C}-9), 46.2\left(\mathrm{CH}_{2}\right), 124.9(\mathrm{C}-7), 127.3(\mathrm{C}-8), 128.4(\mathrm{C}-8 \mathrm{a}), 128.8\left(\mathrm{C}-3^{\prime}+\mathrm{C}-5^{\prime}\right), 129.0(\mathrm{C}-4 \mathrm{a})$, 129.7 (C-2' + C-6'), 131.2 (C-5); 132.7 (C-1'), 132.8 (C-6), 136.5 (C-4'), 144.6 (C-4), 159.0 (C-1) ppm. ESI-MS: $m / z 299.0873[\mathrm{M}+\mathrm{H}]^{+}$; Anal. Calcd for $\mathrm{C}_{17} \mathrm{H}_{15} \mathrm{ClN}_{2} \mathrm{O}: \mathrm{C}, 68.34 ; \mathrm{H}, 5.06 ; \mathrm{N}, 9.38$. Found: C, 68.27; H, 5.04; N, 9.30.

2-Allyl-4-(4-Chlorobenzyl)phthalazin-1(2H)-one (11). Yield 73\%, oil. IR (NaCl): $v_{\max }$ 3073, 2930, 1655, 1586, 1490, 1092, 810, $796 \mathrm{~cm}^{-1} .{ }^{1} \mathrm{H}-\mathrm{NMR} \delta: 4.25$ (s, 2H, H-9), $4.85\left(\mathrm{~m}, 2 \mathrm{H}, \mathrm{CH}_{2}\right), 5.20 / 5.27$ $\left(\mathrm{m}, 2 \mathrm{H},=\mathrm{CH}_{2}\right), 6.06(\mathrm{~m}, 1 \mathrm{H}, \mathrm{CH}=), 7.18\left(\mathrm{~d} . J=8.2 \mathrm{~Hz}, \mathrm{H}-3^{\prime}+\mathrm{H}-5^{\prime}\right), 7.22\left(\mathrm{~d}, J=8.2 \mathrm{~Hz}, 2 \mathrm{H}, \mathrm{H}-2^{\prime}+\right.$ H-6'), 7.67 (m, 3H, H-5 + H-6 + H-7), 8.42 (m, 1H, H-8) ppm. ${ }^{13} \mathrm{C}-\mathrm{NMR} \delta: 38.2(\mathrm{C}-9), 53.4\left(\mathrm{CH}_{2}\right)$, $117.8\left(=\mathrm{CH}_{2}\right), 124.8(\mathrm{C}-7), 127.3(\mathrm{C}-8), 128.3(\mathrm{C}-8 \mathrm{a}), 128.7\left(\mathrm{C}-3^{\prime}+\mathrm{C}-5^{\prime}\right), 129.1(\mathrm{C}-4 \mathrm{a}), 129.6\left(\mathrm{C}-2^{\prime}+\right.$ C-6'), 130.1 (C-1'), 131.2 (C-5); 132.5 (CH=), 132.8 (C-6), 136.2 (C-4'), 144.8 (C-4), 158.9 (C-1) ppm. ESI-MS: $m / z 311.0873[\mathrm{M}+\mathrm{H}]^{+}$; Anal. Calcd for $\mathrm{C}_{18} \mathrm{H}_{15} \mathrm{ClN}_{2} \mathrm{O}: \mathrm{C}, 69.57 ; \mathrm{H}, 4.86 ; \mathrm{N}, 9.01$. Found: C, 69.48; H, 4.80; N, 9.02 .

\subsubsection{General Procedure for the Synthesis of Phthalazinones 17-22}

A solution of the corresponding benzalphthalide $\mathbf{B}(1 \mathrm{~mol})$, methylhydrazine $(3 \mathrm{~mL})$ in dichloromethane $(6 \mathrm{~mL})$ was absorbed in silica gel $(10: 1$ respecting the benzalphthalide). The solvent was removed under vacuum and the mixture MW irradiated $(350 \mathrm{~W})$ for 1-6 minutes. Then, 3 drops of water were added and stirred for $20 \mathrm{~min}$ at room temperature. Ethyl acetate was added to the mixture and the silica gel filtered out. The solvent was removed under vacuum and the crude mixture purified by flash chromatography on silica gel. Phthalazinones 17-19 were obtained as 1:1 mixtures of regioisomers at the $6 / 7$ positions. 
4-(4-Chlorobenzyl)-6(7)-hydroxycarbonyl-2-methylphthalazin-1(2H)-one (17). Yield 90\%, oil. IR $(\mathrm{NaCl}): v_{\max } 3430-2715,1720,1645,1614,1352,1088,803,720 \mathrm{~cm}^{-1}$. ESI-MS: $\mathrm{m} / z \quad 330.0611$ $[\mathrm{M}+\mathrm{H}]^{+}$; Anal. Calcd for $\mathrm{C}_{17} \mathrm{H}_{13} \mathrm{ClN}_{2} \mathrm{O}_{3}: \mathrm{C}, 62.11 ; \mathrm{H}, 3.99 ; \mathrm{N}, 8.52$. Found: C, 62.15; H, 3.90; N, 8.50.

4-(4-Chlorobenzyl)-6-hydroxycarbonyl-2-methylphthalazin-1(2H)-one (17a). ${ }^{1} \mathrm{H}-\mathrm{NMR}\left(\mathrm{CD}_{3} \mathrm{OD}+\right.$ $\left.\mathrm{CDCl}_{3}\right) \delta: 3.88\left(\mathrm{~s}, 3 \mathrm{H}, \mathrm{NCH}_{3}\right), 4.29$ (s, 2H, H-9), 7.18-7.30 (m, 4H, H-2' + H-6' and H-3'+ H-5'), 8.45 (br s, 1H, H-5), 8.33 (d, $J=8.4 \mathrm{~Hz}, 1 \mathrm{H}, \mathrm{H}-7), 7.73$ (d, $J=8.4 \mathrm{~Hz}, 1 \mathrm{H}, \mathrm{H}-8)$ ppm. ${ }^{13} \mathrm{C}-\mathrm{NMR}\left(\mathrm{CD}_{3} \mathrm{OD}+\right.$ $\left.\mathrm{CDCl}_{3}\right)$ \&: $38.0(\mathrm{C}-9), 39.4\left(\mathrm{NCH}_{3}\right), 125.3$ (C-8), 127.7 (C-8a), 128.7 (C-3' + H-5'), 128.9 (C-5), 129.7 (C-2' + H-6'), 130.2 (C-4a), 131.6 (C-4'), 132.6 (C-6), 133.4 (C-7), 135.7 (C-1'), 144.8 (C-4), 159.5 (C-1), $166.7(\mathrm{COOH}) \mathrm{ppm}$.

4-(4-Chlorobenzyl)-7-hydroxycarbonyl-2-methylphthalazin-1(2H)-one (17b). ${ }^{1} \mathrm{H}-\mathrm{NMR}\left(\mathrm{CD}_{3} \mathrm{OD}+\right.$ $\left.\mathrm{CDCl}_{3}\right) \delta: 3.88\left(\mathrm{~s}, 3 \mathrm{H}, \mathrm{NCH}_{3}\right), 4.31(\mathrm{~s}, 2 \mathrm{H}, \mathrm{H}-9), 7.18-7.30\left(\mathrm{~m}, \mathrm{H}-2^{\prime}+\mathrm{H}-6\right.$ ' and H-3' + H-5'), 8.33 (d, $J=8.0 \mathrm{~Hz}, 1 \mathrm{H}, \mathrm{H}-5), 8.49$ (d, $J=8.0 \mathrm{~Hz}, 1 \mathrm{H}, \mathrm{H}-6), 9.09$ (s, $1 \mathrm{H}, \mathrm{H}-8)$ ppm. ${ }^{13} \mathrm{C}-\mathrm{NMR}\left(\mathrm{CD}_{3} \mathrm{OD}+\right.$ $\left.\mathrm{CDCl}_{3}\right)$ \&: $37.8(\mathrm{C}-9), 39.4\left(\mathrm{NCH}_{3}\right), 127.0(\mathrm{C}-8), 127.2$ (C-5), 127.7 (C-8a), 128.7 (C-3' + H-5'), 129.7 (C-2' + H-6'), 130.3 (C-4a), 131.6 (C-6), 131.7 (C-4'), 135.7 (C-1'), 145.5 (C-4), 134.8 (C-7), 159.2 (C-1), $166.5(\mathrm{COOH}) \mathrm{ppm}$.

4-(4-Chlorobenzyl)-6(7)-hydroxymethyl-2-methylphthalazin-1(2H)-one (18). Yield 91\%, Colourless oil. IR $(\mathrm{NaCl}): v_{\max } 3306,1632,1617,1582,1356,1060,844,821 \mathrm{~cm}^{-1}$. ESI-MS: $\mathrm{m} / z 313.0611$ $[\mathrm{M}+\mathrm{H}]^{+}$; Anal. Calcd for $\mathrm{C}_{17} \mathrm{H}_{15} \mathrm{ClN}_{2} \mathrm{O}_{3}: \mathrm{C}, 64.87 ; \mathrm{H}, 4.80 ; \mathrm{N}, 8.90$. Found: C, 64.76; H, 4.70; N, 8.87.

4-(4-Chlorobenzyl)-6-hydroxymethyl-2-methylphthalazin-1(2H)-one (18a). ${ }^{1} \mathrm{H}-\mathrm{NMR} \delta: 3.84$ (s, 3H, $\mathrm{NCH}_{3}$ ), 4.22 (s, 2H, H-9), 4.80 (s, 2H, CH $2 \mathrm{OH}$ ), 7.16-7.22 (m, 4H, H-2'+ H-6'and H-3' + H-5'), 7.60 (d, $J=8.0 \mathrm{~Hz}, 1 \mathrm{H}, \mathrm{H}-7), 7.66$ (s, 1H, H-5), 8.31 (d, $J=8.0 \mathrm{~Hz}, 1 \mathrm{H}, \mathrm{H}-8)$ ppm. ${ }^{13} \mathrm{C}-\mathrm{NMR} \delta: 38.1$ (C-9), $39.5\left(\mathrm{NCH}_{3}\right), 64.3\left(\mathrm{CH}_{2}\right), 122.1(\mathrm{C}-5), 127.2(\mathrm{C}-8 \mathrm{a}), 127.3(\mathrm{C}-8), 128.9\left(\mathrm{C}-7+\mathrm{C}-3^{\prime}+\mathrm{H}-5{ }^{\prime}\right), 129.2$ (C-4a), 129.8 (C-2' + H-6'), 132.6 (C-4'), 136.3 (C-1'), 144.8 (C-4), 146.6 (C-6), 159.6 (C-1) ppm.

4-(4-Chlorobenzyl)-7-hydroxymethyl-2-methylphthalazin-1(2H)-one (18b). ${ }^{1} \mathrm{H}-\mathrm{NMR} \delta: 3.84$ (s, 3H, $\mathrm{NCH}_{3}$ ), 4.23 (s, 2H, H-9), 4.82 (s, 2H, $\left.\mathrm{CH}_{2} \mathrm{OH}\right), 7.16-7.22$ (m, 4H, H-2' + H-6' and H-3' + H-5'), 7.64 (d, $J=8.4 \mathrm{~Hz}, 1 \mathrm{H}, \mathrm{H}-5), 7.72$ (dd, $J=8.4,1.5 \mathrm{~Hz}, 1 \mathrm{H}, \mathrm{H}-6), 8.36$ (br s, $1 \mathrm{H}, \mathrm{H}-8)$ ppm. ${ }^{13} \mathrm{C}-\mathrm{NMR} \delta$ : 38.3 (C-9), $39.5\left(\mathrm{NCH}_{3}\right), 64.3\left(\mathrm{CH}_{2}\right), 124.5(\mathrm{C}-5), 125.3(\mathrm{C}-8), 127.2(\mathrm{C}-8 \mathrm{a}), 128.3(\mathrm{C}-4 \mathrm{a}), 128.9\left(\mathrm{C}-3^{\prime}+\right.$ H-5'), 129.8 (C-2' + H-6'), 131.5 (C-6), 132.6 (C-4'), 136.3 (C-1), 144.6 (C-4), 145.2 (C-7), 159.6 (C-1) ppm.

4-(4-Chlorobenzyl)-6(7)-nitro-2-methylphthalazin-1(2H)-one (19). Yield 53\%, yellowish oil. IR $(\mathrm{NaCl}): v_{\max }$ 2918, 1662, 1618, 1531, 1344, 1090, $794 \mathrm{~cm}^{-1}$. ESI-MS: $m / z 329.0567[\mathrm{M}+\mathrm{H}]^{+}$; Anal. Calcd for $\mathrm{C}_{16} \mathrm{H}_{12} \mathrm{ClN}_{3} \mathrm{O}_{3}$ : C, 58.28; H, 3.67; N, 12.74. Found: C, 58.18; H, 3.72; N, 12.50 .

4-(4-Chlorobenzyl)-6-nitro-2-methylphthalazin-1(2H)-one (19a). ${ }^{1} \mathrm{H}-\mathrm{NMR}(400 \mathrm{MHz}) \delta: 3.82(\mathrm{~s}, 3 \mathrm{H}$, $\left.\mathrm{CH}_{3}\right), 4.23(s, 2 \mathrm{H}, \mathrm{H}-9), 7.08-7.18\left(\mathrm{~m}, 4 \mathrm{H}, \mathrm{H}-3^{\prime}+\mathrm{H}-5^{\prime}+\mathrm{H}-2^{\prime}+\mathrm{H}-6\right.$ '), $8.47(s, 1 \mathrm{H}, \mathrm{H}-5), 7.72(\mathrm{~d}$, $J=8.7 \mathrm{~Hz}, 1 \mathrm{H}, \mathrm{H}-7), 8.53$ (d, $J=8.7 \mathrm{~Hz}, 1 \mathrm{H}, \mathrm{H}-8)$ ppm. ${ }^{13} \mathrm{C}-\mathrm{NMR}(100 \mathrm{MHz}) \delta: 38.5$ (C-9), 39.8 $\left(\mathrm{CH}_{3}\right), 123.3(\mathrm{C}-8), 125.1(\mathrm{C}-5) ; 129.0(\mathrm{C}-8 \mathrm{a}), 129.3$ (C-3' + C-5'), 129.8 (C-7 + C-2' + C-6'), 131.9 (C-4'), 132.8 (C-4a), 135.3 (C-1'), 143.4 (C-4), 149.0 (C-6), 158.4 (C-1) ppm. 
4-(4-Chlorobenzyl)-7-nitro-2-methylphthalazin-1(2H)-one (19b). ${ }^{1} \mathrm{H}-\mathrm{NMR}(400 \mathrm{MHz}) \delta: 3.82(\mathrm{~s}, 3 \mathrm{H}$, $\left.\mathrm{CH}_{3}\right), 4.23$ (s, 2H, H-9), 7.08-7.18 (m, 4H, H-3' + H-5' + H-2'+ H-6'), 8.37 (d, J= 8.4 Hz, 1H, H-6), $8.49(\mathrm{~d}, J=8.4 \mathrm{~Hz}, 1 \mathrm{H}, \mathrm{H}-5), 9.18(\mathrm{~s}, 1 \mathrm{H}, \mathrm{H}-8) \mathrm{ppm} .{ }^{13} \mathrm{C}-\mathrm{NMR}(100 \mathrm{MHz}) \delta: 38.3(\mathrm{C}-9), 39.8\left(\mathrm{CH}_{3}\right)$, 120.7 (C-8), 126.9 (C-6), 129.0 (C-8a), 129.3 (C-3' + C-5'), 129.8 (C-5 + C-2' + C-6'), 131.9 (C-4'), 133.8 (C-4a), 135.5 (C-1'), 143.1 (C-4), 150.2 (C-7), 158.1 (C-1) ppm.

6,7-Dichloro-4-(4-chlorobenzyl)-phthalazin-1(2H)-one (20). Yield 64\%, Colourless oil. IR (NaCl): $v_{\max } 2943,1652,1490,1090,1015,804,732 \mathrm{~cm}^{-1} .{ }^{1} \mathrm{H}-\mathrm{NMR} \delta: 3.85\left(\mathrm{~s}, 3 \mathrm{H}, \mathrm{CH}_{3}\right), 4.20$ (s, 2H, H-9), $7.18\left(\mathrm{~d}, J=8.4,2 \mathrm{H}, \mathrm{H}-2^{\prime}+\mathrm{H}^{-6}\right), 7.28$ (d, $\left.J=8.4 \mathrm{~Hz}, 2 \mathrm{H}, \mathrm{H}-3^{\prime}+\mathrm{H}-5^{\prime}\right), 7.71$ (s, 1H, H-5), 8.49 (s, 1H, H-8) ppm. ${ }^{13} \mathrm{C}-\mathrm{NMR}$ 8: 38.1 (C-9), $39.6\left(\mathrm{CH}_{3}\right), 126.7$ (C-8), 127.5 (C-8a), $128.4\left(\mathrm{C}-1^{\prime}\right), 129.1(\mathrm{C}-5+$ C-3' + C-5'), 129.7 (C-2' + C-6'), 133.0 (C-4'), 135.5 (C-7), 136.5 (C-4a), 138.0 (C-6), 143.0 (C-4), 157.9 (C-1) ppm. ESI-MS: $m / z 352.9937[\mathrm{M}+\mathrm{H}]^{+}$; Anal. Calcd for $\mathrm{C}_{16} \mathrm{H}_{11} \mathrm{Cl}_{3} \mathrm{~N}_{2} \mathrm{O}: \mathrm{C}, 54.34 ; \mathrm{H}, 3.14$; N, 7.92. Found: C, 54.40; H, 3.07; N, 7.79.

6,7-Dichloro-4-(2,4-dichlorobenzyl)-phthalazin-1(2H)-one (21). Yield 86\%, oil. IR (NaCl): $v_{\max } 2923$, 1660, 1581, 1471, 1128, 1101, $850 \mathrm{~cm}^{-1} .{ }^{1} \mathrm{H}-\mathrm{NMR}(400 \mathrm{MHz}) 3.80$ (s, 3H, CH ), 4.20 (s, 2H, H-9), 7.03 (d, $\left.J=8.0 \mathrm{~Hz}, 1 \mathrm{H}, \mathrm{H}-6^{\prime}\right), 7.15$ (dd, $\left.J=8.0,1.7 \mathrm{~Hz}, 1 \mathrm{H}, \mathrm{H}-5^{\prime}\right), 7.47$ (d, $\left.J=1.7 \mathrm{~Hz}, 1 \mathrm{H}, \mathrm{H}-3^{\prime}\right), 7.76$ (s, 1H, H-5), 8.53 (s, 1H, H-8) ppm. ${ }^{13} \mathrm{C}-\mathrm{NMR} \delta: 35.0$ (C-9), $39.5\left(\mathrm{CH}_{3}\right), 126.3(\mathrm{C}-8), 127.3(\mathrm{C}-8 \mathrm{a})$, 127.4 (C-5'), 128.4 (C-1'), 129.1 (C-5), 129.5 (C-3'), 131.0 (C-6'), 133.3 (C-2'), 133.6 (C-4'), 134.3 (C-7), 136.6 (C-4a), 138.2 (C-6), 142.0 (C-4), 158.0 (C-1) ppm. ESI-MS: $m / z 386.9547$ [M+H] ${ }^{+}$; Anal. Calcd for $\mathrm{C}_{16} \mathrm{H}_{10} \mathrm{Cl}_{4} \mathrm{~N}_{2} \mathrm{O}$ : C, 49.52; H, 2.60; N, 7.22. Found: C, 49.43; H, 2.71; N, 7.14.

6,7-Dichloro-4-(3,4-dichlorobenzyl)-phthalazin-1(2H)-one (22). Yield 89\%, oil. IR (NaCl): $v_{\max } 2921$, 1651, 1618, 1470, 1347, 1031, $823 \mathrm{~cm}^{-1} .{ }^{1} \mathrm{H}-\mathrm{NMR} \delta: 3.81$ (s, 3H, $\left.\mathrm{CH}_{3}\right), 4.25$ (s, 2H, H-9), 7.09 (d, $\left.J=8.6 \mathrm{~Hz}, 1 \mathrm{H}, \mathrm{H}-6^{\prime}\right), 7.10$ (d, $\left.J=8.6 \mathrm{~Hz}, 1 \mathrm{H}, \mathrm{H}-5^{\prime}\right), 7.40$ (br s, 1H, H-2'), 7.80 (s, 1H, H-5), 8.49 (s, 1H, H-8) ppm. ${ }^{13} \mathrm{C}-\mathrm{NMR} \delta: 37.8$ (C-9), $39.6\left(\mathrm{CH}_{3}\right), 126.1$ (C-8), 127.3 (C-8a), 128.1 (C-5'), 129.0 (C-5), 130.8 (C-6'), 131.9 (C-2'), 132.3 (C-3'), 133.5 (C-4'), 133.9 (C-7), 136.3 (C-4a), 137.5 (C-1'), 138.3 (C-6), 143.1 (C-4), 158.2 (C-1) ppm. ESI-MS: $m / z 386.9547[\mathrm{M}+\mathrm{H}]^{+}$; Anal. Calcd for $\mathrm{C}_{16} \mathrm{H}_{10} \mathrm{Cl}_{4} \mathrm{~N}_{2} \mathrm{O}: \mathrm{C}$, 49.52; H, 2.60; N, 7.22. Found: C, 49.61; H, 2.53; Cl, 36.57; N, 7.17.

\subsubsection{Synthesis of Phthalazinone Carboxymethyl ester $\mathbf{2 3}$}

The phthalazinone 17 (20 mg, 0,06 mmoles) was treated with a saturated solution diazomethane in ether $(2 \mathrm{~mL})$, and maintaind in darkness at room temperature overnight. The solvent was removed to give $22 \mathrm{mg}(99 \%)$ of the ester $\mathbf{2 3}$, as a regioisomeric mixture.

4-(4-Chlorobenzyl)-6(7)-methoxycarbonyl-2-methylphthalazin-1(2H)-one (23). Oil. IR (NaCl): $v_{\max }$ 2928, 1704, 1652, 1614, 1490, 1347, 1090, 1015, $845 \mathrm{~cm}^{-1}$. ESI-MS: $m / z 343.0771[\mathrm{M}+\mathrm{H}]^{+}$; Anal. Calcd for $\mathrm{C}_{18} \mathrm{H}_{15} \mathrm{ClN}_{2} \mathrm{O}_{3}$ : C, 63.07; H, 4.41; N, 8.17. Found: C, 62.97; H, 4.51; N, 8.22.

4-(4-Chlorobenzyl)-6-methoxycarbonyl-2-methylphthalazin-1(2H)-one (23a). ${ }^{1} \mathrm{H}-\mathrm{NMR} \delta: 3.88$ (s, 3H, $\left.\mathrm{CH}_{3}\right), 3.97$ (s, 3H, $\left.\mathrm{OCH}_{3}\right), 4.28$ (s, 2H, H-9), 7.19 (d, J=8.8 Hz, 2H, H-3' + H-5'), 7.27 (d, J=8.8 Hz, 2H, H-2' + H-6'), 7.70 (d, $J=8.8 \mathrm{~Hz}, 1 \mathrm{H}, \mathrm{H}-7), 8.29$ (d, $J=8.8 \mathrm{~Hz}, 1 \mathrm{H}, \mathrm{H}-8), 8.40$ (s, 1H, H-5) ppm. ${ }^{13} \mathrm{C}-\mathrm{NMR} \delta$ : $38.2(\mathrm{C}-9), 39.6\left(\mathrm{CH}_{3}\right), 52.7\left(\mathrm{OCH}_{3}\right), 125.4(\mathrm{C}-5) ; 128.2(\mathrm{C}-8 \mathrm{a}), 129.0\left(\mathrm{C}-8+\mathrm{C}-3^{\prime}+\mathrm{C}-5^{\prime}\right)$, 
129.8 (C-2' + C-6'), 131.3 (C-7), 132.0 (C-4'), 133.0 (C-4a), 133.1 (C-6), 136.0 (C-1'), 144.1 (C-4), 159.1 (C-1), 165.6 (COO) ppm.

4-(4-Chlorobenzyl)-7-methoxycarbonyl-2-methylphthalazin-1(2H)-one (23b). ${ }^{1} \mathrm{H}-\mathrm{NMR} \delta: 3.88$ (s, 3H, $\left.\mathrm{CH}_{3}\right), 3.97$ (s, 3H, $\left.\mathrm{OCH}_{3}\right), 4.30$ (s, 2H, H-9), 7.19 (d, J=8.8 Hz, 2H, H-3' + H-5'), 7.27 (d, J= 8.8 Hz, $2 \mathrm{H}, \mathrm{H}-2^{\prime}+\mathrm{H}^{-6}$ ), 8.29 (d, $\left.J=8.4 \mathrm{~Hz}, 1 \mathrm{H}, \mathrm{H}-6\right), 8.51$ (d, $\left.J=8.4 \mathrm{~Hz}, 1 \mathrm{H}, \mathrm{H}-5\right), 9.03$ (s, 1H, H-8). ${ }^{13} \mathrm{C}-\mathrm{NMR}$ 8: $38.4(\mathrm{C}-9), 39.6\left(\mathrm{CH}_{3}\right), 52.7\left(\mathrm{OCH}_{3}\right), 126.9(\mathrm{C}-5) ; 127.8(\mathrm{C}-8), 128.2(\mathrm{C}-8 \mathrm{a}), 129.0$ (C-3' + C-5'), 129.8 (C-2' + C-6'), 132.0 (C-4'), 132.6 (C-4a), 132.9 (C-6), 134.0 (C-7), 136.0 (C-1'), 144.8 (C-4), 159.1 (C-1), 165.6 (COO).

\subsubsection{Synthesis of the Phthalazinone Aldehyde $\mathbf{2 4}$}

To a three-neck round-bottom flask filled with dichloromethane $(15 \mathrm{~mL})$ and a stirring bar, two compensated pressure addition funnels were adapted. Air was removed, the system filled with Ar and taken to $-55^{\circ} \mathrm{C}$, then a solution of $2 \mathrm{M}$ oxallyl chloride in dichloromethane $(1.10 \mathrm{~mL}, 2.20 \mathrm{mmol})$ was added. Five min later a mixture of dimethylsulfoxide $(0.4 \mathrm{~mL}, 4.44 \mathrm{mmol})$ in dichloromethane $(2.3 \mathrm{~mL})$ was added dropwise. After $5 \mathrm{~min}$ a solution of phthalazinone 18 (230 $\mathrm{mg}, 0.73 \mathrm{mmol})$ in dichloromethane $(6.5 \mathrm{~mL})$ was added slowly. The mixture was maintained with stirring for $30 \mathrm{~min}$ at $-55^{\circ} \mathrm{C}$. Then, triethylamine $(1.0 \mathrm{~mL}, 7.20 \mathrm{mmol})$ was added and the mixture taken to $0{ }^{\circ} \mathrm{C}$ for $60 \mathrm{~min}$. Then, water $(5 \mathrm{~mL})$ was added to the mixture, which was transferred to a separatory funnel, where it was washed with aqueous solutions of $2 \mathrm{~N} \mathrm{HCl}, \mathrm{NaHCO}_{3}$ (saturated) and $\mathrm{NaCl}$ to $\mathrm{pH}=7$. The organic layer was dried over $\mathrm{Na}_{2} \mathrm{SO}_{4}$, concentrated under reduced pressure to give a crude mixture, that was purified by flash chromatography on silica gel in $\mathrm{CH}_{2} \mathrm{Cl}_{2} / \mathrm{AcOEt}$ (9:1) to provide $138 \mathrm{mg}$ (61\%) of aldehyde 24.

4-(4-Chlorobenzyl)-6(7)-formyl-2-methylphthalazin-1(2H)-one (24). Oil. IR (NaCl): $v_{\max }$ 2928, 1704, 1652, 1614, 1490, 1347, 1090, 1015, $845 \mathrm{~cm}^{-1}$. ESI-MS: $m / z 313.0666[\mathrm{M}+\mathrm{H}]^{+}$; Anal. Calcd. for $\mathrm{C}_{17} \mathrm{H}_{13} \mathrm{ClN}_{2} \mathrm{O}_{2}$ : C, 65.29; H, 4.19; N, 8.96. Found: C, 65.31; H, 4.12; N, 8.83.

4-(4-Chlorobenzyl)-6-formyl-2-methylphthalazin-1(2H)-one (24a). ${ }^{1} \mathrm{H}-\mathrm{NMR} \delta: 3.89$ (s, 3H, $\left.\mathrm{CH}_{3}\right), 4.32$ (s, 2H, H-9), 7.19 (d, J=8.8 Hz, 2H, H-3' + H-5'), 7.29 (d, J=8.8 Hz, 2H, H-2' + H-6'), 8.17 (s, 1H, $\mathrm{H}-5), 8.18$ (d, $J=8.8 \mathrm{~Hz}, 1 \mathrm{H}, \mathrm{H}-7), 8.61$ (d, $J=8.8 \mathrm{~Hz}, 1 \mathrm{H}, \mathrm{H}-8), 10.10$ (s, 1H, CHO) ppm. ${ }^{13} \mathrm{C}-\mathrm{NMR}$

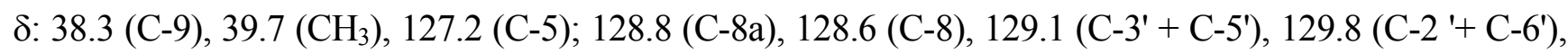
130.7 (C-7), 131.9 (C-4a), 133.0 (C-4'), 135.8 (C-1'), 138.9 (C-6), 144.8 (C-4), 158.8 (C-1), 190.8 (CHO) ppm.

4-(4-Chlorobenzyl)-7-formyl-2-methylphthalazin-1(2H)-one (24b). ${ }^{1} \mathrm{H}-\mathrm{NMR} \delta: 3.90$ (s, 3H, $\left.\mathrm{CH}_{3}\right), 4.29$ (s, 2H, H-9), 7.19 (d, $\left.J=8.8 \mathrm{~Hz}, 2 \mathrm{H}, \mathrm{H}-3^{\prime}+\mathrm{H}-5^{\prime}\right), 7.29$ (d, $J=8.8 \mathrm{~Hz}, 2 \mathrm{H}, \mathrm{H}-2^{\prime}+\mathrm{H}-6$ '), 7.77 (d, J = 8.4 Hz, $1 \mathrm{H}, \mathrm{H}-6), 8.17$ (d, $J=8.4 \mathrm{~Hz}, 1 \mathrm{H}, \mathrm{H}-5), 8.90$ (br s, $1 \mathrm{H}, \mathrm{H}-8), 10.17$ (s, 1H, CHO) ppm. ${ }^{13} \mathrm{C}-\mathrm{NMR} \delta$ : 38.3 (C-9), $39.7\left(\mathrm{CH}_{3}\right), 126.1$ (C-5); 128.8 (C-8a), 129.1 (C-3'+C-5'), $129.6(\mathrm{C}-8), 129.8\left(\mathrm{C}-2^{\prime}+\right.$ C-6'), 131.3 (C-6), 133.0 (C-4'), 135.8 (C-1'), 137.8 (C-4a), 138.9 (C-7), 144.1 (C-4), 159.0 (C-1), 190.7 (CHO) ppm. 


\subsubsection{Synthesis of the 6(7)hydroxylimino-phthalazinone $\mathbf{2 5}$}

To a solution of $24(100 \mathrm{mg}, 0.32 \mathrm{mmol})$ in ethanol $(5 \mathrm{~mL})$, dry pyridine $(83 \mu \mathrm{L}, 1.03 \mathrm{mmol})$ and hydroxylamine clorhydrate $(25 \mathrm{mg}, 0.35 \mathrm{mmol})$ were added. The mixture was refluxed under stirring for 2 hours. Solvents were removed under vacuum and the mixture dissolved in ethyl acetate. The organic layer was washed with solutions of $2 \mathrm{~N} \mathrm{HCl}$ and $\mathrm{NaCl}$ to $\mathrm{pH}=7$, dried over $\mathrm{Na}_{2} \mathrm{SO}_{4}$, and taken do dryness to give $95 \mathrm{mg}$ (92\%) of the regioisomers 25 .

4-(4-Chlorobenzyl)-6(7)-hydroxylimino-2-methylphthalazin-1(2H)-one (25). Oil. IR (NaCl): $v_{\max } 3441$, 2927, 1632, 1579, 1111, 995, 796, $674 \mathrm{~cm}^{-1}$. ESI-MS: $\mathrm{m} / z 328.0775[\mathrm{M}+\mathrm{H}]^{+}$; Anal. Calcd for $\mathrm{C}_{17} \mathrm{H}_{14} \mathrm{ClN}_{3} \mathrm{O}_{2}$ : C, 62.30; H, 4.31; N, 12.82. Found: C, 62.35; H, 4.38; N, 12.83 .

4-(4-Chlorobenzyl)-6-hydroxylimino-2-methylphthalazin-1(2H)-one (25a). ${ }^{1} \mathrm{H}-\mathrm{NMR} \quad(400 \mathrm{MHz}$,

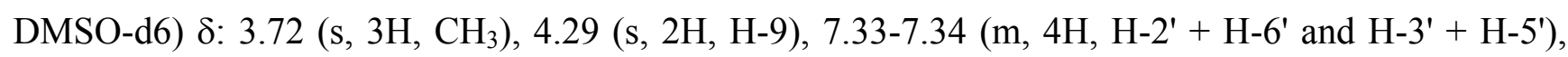
$7.90(\mathrm{~d}, J=8.5 \mathrm{~Hz}, 1 \mathrm{H}, \mathrm{H}-8), 8.04$ (d, $J=8.5 \mathrm{~Hz}, 1 \mathrm{H}, \mathrm{H}-7), 8.33$ (s, 1H, HC=N), 8.41 (s, 1H, H-5) ppm. ${ }^{13} \mathrm{C}-\mathrm{NMR}(100 \mathrm{MHz}) \delta$ : 36.8 (C-9), $39.1\left(\mathrm{CH}_{3}\right), 124.3$ (C-5); 126.2 (C-8), 127.8 (C-4a), 128.5 (C-3' + C-5'), 128.7 (C-8a), 130.0 (C-7), 130.3 (C-2' + C-6'), 131.2 (C-4'), 136.2 (C-6), 144.3 (C-4), $137.0\left(\mathrm{C}-1^{\prime}\right), 147.1(\mathrm{HC}=\mathrm{N}) 158.2(\mathrm{C}-1), \mathrm{ppm}$.

4-(4-Chlorobenzyl)-7-hydroxylimino-2-methylphthalazin-1(2H)-one (25b). ${ }^{1} \mathrm{H}-\mathrm{NMR} \quad(400 \mathrm{MHz}$,

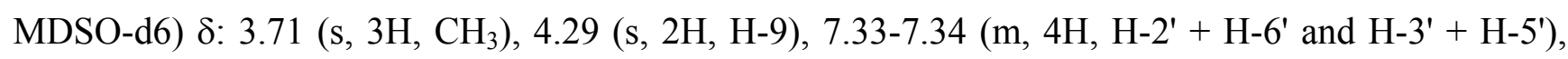
$8.04(\mathrm{~d}, J=8.4 \mathrm{~Hz}, 1 \mathrm{H}, \mathrm{H}-6), 8.33(\mathrm{~s}, 1 \mathrm{H}, \mathrm{HC}=\mathrm{N}), 8.50(\mathrm{~d}, J=8.4 \mathrm{~Hz}, 1 \mathrm{H}, \mathrm{H}-5), 8.60$ (d, $J=8.5 \mathrm{~Hz}$, 1H, H-8 ppm. ${ }^{13} \mathrm{C}-\mathrm{NMR}(100 \mathrm{MHz}) \delta: 38.8(\mathrm{C}-9), 39.1\left(\mathrm{CH}_{3}\right), 123.9(\mathrm{C}-5) ; 127.6(\mathrm{C}-8), 127.9(\mathrm{C}-8 \mathrm{a})$, 128.0 (C-4a), 128.5 (C-3' + C-5'), 130.3 (C-6 + C-2'+C-6'), 131.2 (C-4'), 137.0 (C-7 + C-1'), 144.3 (C-4), $147.1(\mathrm{HC}=\mathrm{N}) 158.2(\mathrm{C}-1) \mathrm{ppm}$.

\subsection{Antifungal Evaluation}

\subsubsection{Microorganisms And Media}

For the antifungal evaluation, standardized strains from the American Type Culture Collection (ATCC), Manassas, Virginia, USA, and Culture Collection of the Reference Center of Mycology (CCC), Faculty of Biochemical and Pharmacuetical Sciences, Suipacha 531-(2000)-Rosario, Argentina were used in a first instance of screening: C. albicans ATCC 10231, S. cerevisiae ATCC 9763, C. neoformans ATCC 32264, A. flavus ATCC 9170, A. fumigatus ATTC 26934, A. niger ATCC 9029, T. rubrum CCC 110, T. mentagrophytes ATCC 9972, M. gypseum CCC 115, M. canis CCC 113 and E. floccosum CCC 112.

Active compounds were tested against clinical isolates from the Malbrán Institute [(MI), Av. Velez Sarsfield 563. Buenos Aires)]. The isolates included eight strains of $C$. neoformans. The voucher specimen numbers are presented in Table 3. Strains were grown on Sabouraud-chloramphenicol agar slants for $48 \mathrm{~h}$ at $30{ }^{\circ} \mathrm{C}$, maintained on slopes of Sabouraud-dextrose agar (SDA, Oxoid, Hampshire, UK) and sub-cultured every $15 \mathrm{~d}$ to prevent pleomorphic transformations. Inocula of cell or spore suspensions were obtained according to reported procedures and adjusted to $1-5 \times 10^{3}$ cells/spores with colony forming units (CFU) per mL $[18,19]$. 


\subsubsection{Antifungal Susceptibility Testing}

Minimum Inhibitory Concentration (MIC) of each compound was determined by using broth microdilution techniques according to the guidelines of the Clinical and Laboratory Standards Institute (CLSI, formerly National Committee for Clinical Laboratory Standards, NCCLS) for yeasts (M27-A3) and for filamentous fungi (M 38 A2) [18,19].

MIC values were determined in RPMI-1640 (Sigma, St. Louis, MO, USA) buffered to pH 7.0 with MOPS. Microtiter trays were incubated at $35{ }^{\circ} \mathrm{C}$ for yeasts and at $28-30{ }^{\circ} \mathrm{C}$ for the rest of fungi in a moist, dark chamber, and MICs were visually recorded at $48 \mathrm{~h}$ for yeasts, and at a time according to the control fungus growth, for the rest of fungi.

For the assay, stock solutions of pure compounds were two-fold diluted with RPMI from $250-0.98 \mu \mathrm{g} / \mathrm{mL}$ (final volume $=100 \mu \mathrm{L}$ ) and a final DMSO concentration $\leq 1 \%$. A volume of $100 \mu \mathrm{L}$ of inoculum suspension was added to each well with the exception of the sterility control where sterile water was added to the well instead. Terbinafine, amphotericin B, voriconazole and itraconazole, were used as positive controls.

Endpoints were defined as the lowest concentration of drug resulting in total inhibition $\left(\mathrm{MIC}_{100}\right)$ of visual growth compared to the growth in the control wells containing no antifungal. $\mathrm{MIC}_{80}$ and $\mathrm{MIC}_{50}$ were defined as the lowest concentration of a compound that induced $80 \%$ or $50 \%$ reduction of the growth control respectively (culture media with the microorganism but without the addition of any compound) and was determined spectrophotometrically with the aid of a VERSA Max microplate reader (Molecular Devices, Sunnyvale, CA, USA).

\subsection{Computational Methods}

All calculations were carried out using the Gaussian 03 program [25]. The search for low-energy conformations on the potential energy surface for compound $\mathbf{5}$ was carried out by first using semiempirical PM6 calculations. Subsequently, DFT (B3LYP/6-31G $(d, p)$ ) calculations were used in the geometry optimisation jobs. Minima were characterized through harmonic frequency analysis. Correlations effects were included using Density Functional Theory (DFT) with the Becke-3-LeeYang-parr (RB3LYP) [26] functional and 6-31++G(d,p) basis set for all complexes obtained at the lower level of computation. During the DFT calculations, the RHF/6-31G geometries were kept fixed.

Potential energy curves (PEC) have been obtained via one-dimensional (1D)-scans using DFT (B3LYP/6-31G $(\mathrm{d}, \mathrm{p})$ ) calculations. In these curves the energy has been calculated at $30^{\circ}$ intervals of the dihedral angles.

The electronic study of the compounds was carried out by using molecular electrostatic potentials. MEPs have been shown to provide reliable information, both on the interaction sites of the molecules with point charges and on the comparative reactivities of these sites [27]. These MEPs were calculated using B3LYP/6-311++G(d,p) single point calculations from the MOLEKEL program [28].

\section{Conclusions}

In summary, we have described here a group of 2-methylphthalazin-1 $(2 H)$-one derivatives acting as antifungal agents. Among them, the compound 4-(4-chlorobenzyl)-2-methylphthalazin-1(2H)-one (5) 
exhibited remarkable antifungal activity against dermatophytes and against $C$. neoformans standardized strains, as well as against a number of clinical isolates. Complementarily, we have carried out a structural molecular and electronic study on compound $\mathbf{5}$ to reveal the conformational and electronic characteristics of this compound. Predictions of ADME, absorption and distribution parameters and the calculated physicochemical properties $(\log \mathrm{S}=-4.4, \log \mathrm{P}=3.7)$ for compound 5 and its analogues, are within the typical ranges desired for a drug, as well as the fulfillment of Lipinski's rule permit us to consider this substance as a good lead compound for antifungal activity. All these aspects serve to justify future research on new series of phthalazinones focused on the structural optimization that could lead to a substantial improvement of potency and antifungal activity spectrum. Such research must be complemented with in vivo toxicity and efficacy evaluations and the elucidation of the mechanism of action.

\section{Acknowledgments}

This work is a collaborative research performed under the auspices of "Programa Iberoamericano de Ciencia y Tecnología para el Desarrollo - CYTED X.7”, and supported by grants from Spanish ISCIII (RD06/0021/0022 to A.S.F.), from Argentineana Agencia Nacional de Promoción Científica y Tecnológica (ANPCyT PICT 0608 to S.Z. and PICT to D.E). B.B. and A.E.G-C thank to the EC-ALFA Program and the Spanish MEC their respective $\mathrm{PhD}$ fellowships. R.D.E. is member of the Consejo Nacional de Investigaciones Científicas y Técnicas (CONICET-Argentina) staff.

\section{References}

1. Mathew, B.; Nath, M. Recent approaches to antifungal therapy for invasive mycoses. ChemMedChem 2009, 4, 310-323.

2. Monk, B.; Goffeau, A. Outwitting multidrug resistance to antifungals. Science 2008, 321, 367-369.

3. Chen, S.; Playford, E.; Sorrell, T. Antifungal therapy in invasive fungal infections. Curr. Opin. Pharmacol. 2010, 10, 522-530.

4. Olivella, M.; Rodríguez, A.M.; Zacchino, S.A.; Somlai, C.; Penke, B.; Farkas, V.; Perczel, A.; Enriz, R.D. New antifungal peptides. Synthesis, bioassays and initial structure prediction by CD spectroscopy. Bioorg. Med. Chem. Lett. 2010, 20, 4808-4811.

5. Yunes, R.; Leal, P.; Mascarello, A.; Derita, M.; Zuljan, F.; Nunes, R.; Zacchino, S. Relation between lipophilicity of alkyl gallates and antifungal activity against yeasts and filamentous fungi. Bioorg. Med. Chem. Lett. 2009, 19, 1793-1796.

6. Masman, M.; Rodríguez, A.; Raimondi, M.; Zacchino, S.; Luiten, P.; Somlai, C.; Kortvelyesi, T.; Penke, B.; Enriz, R. Penetratin and derivatives acting as antifungal agents. Eur. J. Med. Chem. 2009, 44, 212-228.

7. Escalante, A.; Gattuso, M.; Pérez, P.; Zacchino, S. Evidence for the mechanism of action of the antifungal phytolaccoside B from Phytolacca tetramera. J. Nat. Prod. 2008, 71, 1720-1725.

8. Kouznetsov, V.; Vargas, L.; Sortino, M.; Vasquez, Y.; Gupta, M.; Freile, M.; Enriz, R.; Zacchino, S. Antifungal and cytotoxic activities of some N-substituted aniline derivatives bearing an hetaryl fragment. Bioorg. Med. Chem. 2008, 16, 794-809. 
9. Sortino, M.; Cechinel Filho, V.; Correa R.; Zacchino, S. $N$-phenyl and $N$-phenylalkyl-maleimides acting against Candida spp.: time-to-kill, stability, interaction with maleamic acids. Bioorg. Med. Chem. 2008, 16, 560-568.

10. Mohamed, F.K. Synthesis, reactions and antimicrobial activity on some novel phthalazinones derivatives. Der Chemica Sinica 2010, 1, 20-31.

11. Abd El-Wahab, A.H.; Mohamed, H.M.; El-Agrody, A.M.; El-Nassag, M.A.; Bedair, A.H. Synthesis and Biological Screening of 4-Benzyl-2H-phthalazine derivatives. Pharmaceuticals 2011, 4, 1158-1170.

12. Sridhara, K.R.; Reddy, K.R.V.; Keshavayya, J.; Ambika, D.S.; Goud, S.; Peethambar, S.K. Synthesis and antimicrobial studies of some new 3-isoxazoline substituted phthalazine methylsulfonyl oxadiazoles. Eur. J. Chem. 2011, 8, 1022-1029.

13. Sridhara, A.M.; Reddy, K.R.V.; Keshavayya, J.; Ambika, D.M.S.; Gopinath, V. Bose, P.; Goud, S.K.; Peethambar, S.K. Synthesis, Antimicrobial and Cytotoxicity Studies of Some Novel Modified Strobilurin Derivatives. J. Braz. Chem. Soc. 2011, 22, 849-856.

14. Sridhara, A.M.; Reddy, K.R.V.; Keshavayya, J.; Goud, P.S.K.; Somashekar, B.C.; Bose, P.; Peethambar, S.K.; Gaddam, S.K. Synthesis and antimicrobial activity of 2-substituted [4-(1,3,4oxadiazol-2-yl methyl)] phthalazin-1(2H)-one derivatives. Eur. J. Med. Chem. 2010, 45, 4983-4989.

15. Ryu, C.K.; Kim, D.H.; Lee, I.K.; Kim, S.J. The evaluation of in vitro antifungal activities of 6-[(N-4-fluorophenyl)amino]-7-chloro-5,8-quinolinedione. Yakhak Hoeji 1996, 40, 90-94.

16. Zamilpa, A.; Herrera-Ruiz, M.; del Olmo, E.; López-Pérez, J.L.; Anxiolytic effects of benzalphthalides. Bioorg. Med. Chem. Lett. 2005, 15, 3483-3486.

17. Nascimento-Júnior, N.M.; Kümmerle, A.E.; Barreiro, E.J.; Fraga, C.A.M. MAOS and Medicinal Chemistry: Some Important Examples from the Last Years. Molecules 2011, 16, 9274-9297.

18. Clinical and Laboratory Standards Institute (CLSI). Document M27-A3, 3rd ed.; NCCLS: Wayne, PA, USA, 2008; Volume 28, pp. 1-25.

19. Clinical and Laboratory Standards Institute (CLSI). Document M38-A2, 2nd ed.; NCCLS: Wayne, PA, USA, 2008; Volume 28, pp. 1-35.

20. Singh, N. Treatment of opportunistic mycoses: how long is long enough? Lancet Infect. Dis. 2003, 3, 703-707.

21. Polak, A. The past, Present and future of antimycotic combination therapy. Mycoses 1999, 42, 355-370.

22. Insuasty, B.; Gutiérrez, A.; Quiroga, J.; Abonia, R.; Nogueras, M.; Cobo, J.; Svetaz, L.; Raimondi, M.; Zacchino, S. Fungicide activity of 5-(4-chlorobenzylidene)-(Z)-2-dimethylamino1,3-thiazol-4-one against Cryptococcus neoformans. Arch. Pharm. Chem. Life Sci. 2010, 343, 48-53.

23. Ernst, E.; Roling, E.; Petzold, R.; Keele, D.; Klepser, M. In vitro activity of micafungin (FK-463) against Candida spp: Microdilution, time-kill, and postantifungal-effect studies. Antimicrob. Agents Chemother. 2002, 46, 3846-3853.

24. Armarego, W.L.F.; Perrin, D.D. Purification of Laboratory Chemicals, 4th ed.; Pergamon Press: Oxford, UK, 2000.

25. Frisch, M.J.; Trucks, G.W.; Schlegel, H.B.; Scuseria, G.E.; Robb, M.A.; Cheeseman, J.R.; Montgomery, J.A., Jr.; Vreven, T.; Kudin, K.N.; Burant, J.C.; et al. GAUSSIAN 03, Revision B.01; Gaussian, Inc.: Wallingford, CT, USA, 2004. 
26. Lee, C.; Yang, W.; Parr, R. Development of the Colle-Salvetti correlation energy formula into a functional of the electron density. Phys. Rev. B 1988, 37, 785-789.

27. Polilzer, P.; Truhlar, D.G. Chemical Applications of Atomic and Molecular Electrostatic Potentials; Plenum Publishing: New York, NY, USA, 1981; p. 34.

28. Flükiger, P.; Lüthi, H.P.; Portmann, S.; Weber, J. MOLEKEL 4.0; Swiss Center for Scientific Computing: Manno, Switzerland, 2000.

Sample Availability: Samples of the compounds 1-25 are available from the authors.

(C) 2013 by the authors; licensee MDPI, Basel, Switzerland. This article is an open access article distributed under the terms and conditions of the Creative Commons Attribution license (http://creativecommons.org/licenses/by/3.0/). 